\title{
In the trap of interacting indirect and direct drivers: the disintegration of extensive, traditional grassland management in Central and Eastern Europe
}

\author{
$\underline{\text { Dániel Babai }}^{1}$ Béla Jánó $^{2}$ and Zsolt Molnár ${ }^{3}$
}

\begin{abstract}
Micro-scale management of cultural landscapes with species-rich grasslands requires the operation of extensive, traditional land-use systems. These social-ecological systems are under increasing pressure of interacting drivers that impact on farmers' individual decisions and force them to make trade-offs. We aimed to reveal the local understanding of driver interactions and related trade-offs focusing on a key element of a traditional social-ecological system. We studied the time of hay-mowing using participatory observation (105 field days), semi-structured interviews $(n=85)$, and focus group discussions $(n=2)$, analyzing the interacting IPBESdefined drivers that influence the choice of the time of mowing and related trade-offs in a small-scale community in a mountainous landscape (Gyimes, Transylvania, Romania) from the 1950s to the present. Local farmers perceived a number of direct and indirect drivers, as ecological, socio-cultural, economic, and political changes affected the optimal and actual time of mowing and increased the number of trade-offs. The most important factors were (1) the quality of the hay; (2) long-term yield stability by ensuring seed ripening, and (3) qualifying for financial support from agri-environment-climate schemes. Direct drivers influenced the phenology of vegetation and thus the time of mowing, while indirect social, cultural, and political drivers only impacted on the latter. The complexity of driver and trade-off interactions increased through time making adaptation more difficult. While farmers were navigating through the increased complexity, an informal social institution that previously optimized the work forces of farms gradually disappeared. The cumulative effects of drivers and trade-offs decreased the economic and social viability of the system. Our results suggest that the local community's adaptive capacity has been drastically weakened. We argue that more flexible and adaptive regulations are needed to assure the continuity and ongoing adaptation of this and other Eastern-Central-European, centuries-old but still existing traditional management systems, which created and maintain high nature-value cultural landscapes.
\end{abstract}

Key Words: agri-environment-climate schemes; Carpathians; cultural landscapes; land-use change; Natura 2000; qualitative approach; time of mowing

\section{INTRODUCTION}

European cultural landscapes, as high-nature-value farmlands, are diverse habitat mosaics with a large proportion of seminatural vegetation, possessing outstanding cultural and nature conservation values (Plieninger et al. 2006, Fischer et al. 2012, Lieskovský et al. 2014). Sustaining cultural landscapes requires small-scale farmer communities operating extensive, traditional land-use systems (Poschlod et al. 1998). These land-use systems are locally adapted and are characterized by low-intensity practices (low agrochemical input and machinery) and a reliance on the intensive input of human labor, and they manage all the natural resources and habitats important for the local communities (Bignal and McCracken 2000, Plieninger et al. 2006, Babai and Molnár 2014, Dorresteijn et al. 2015, Sutcliffe et al. 2015a, McGinlay et al. 2017). Recently, nature conservation has made attempts to model and take over the role of previous extensive, traditional land-use practices as a means of maintaining valuable cultural landscapes (Plieninger et al. 2006, Dahlström et al. 2013, Biró et al. 2019, Molnár et al. 2020). Particular scientific and socio-political attention should therefore be devoted to the traditional land-use systems that still operate sporadically in order to learn more about how they function.

Extensive, traditional land-use systems with diverse functions (agricultural production, the maintenance of biodiversity, social coherence, and cultural dimensions; Sutcliffe et al. 2015b), are affected by a large number of direct and indirect drivers (MacDonald et al. 2000, Henle et al. 2008, Balázsi et al. 2019).
Direct drivers, e.g., climate change or land-use changes, are natural and anthropogenic pressures directly affecting the functioning of biological components of social-ecological systems, e.g., biodiversity or ecosystem processes. Economic, demographic, cultural, etc. changes are regarded as indirect drivers, influencing formal and informal social institutions, and affecting direct drivers as well (Díaz et al. 2015). The impact of these drivers is often compounded, although conversely, they may also cancel each other out; they are difficult to separate and are often hidden or delayed (Nelson et al. 2006, Hanspach et al. 2014, Elbakidze et al. 2018). These drivers have led to a significant decline in extensive land-use systems across Europe (MacDonald et al. 2000). Changes are usually binarily interpreted, i.e., abandonment and/or intensification of extensive management (Bignal and McCracken 2000, MacDonald et al. 2000, Dahlström et al. 2013, Sutcliffe et al. 2015b, Lasanta et al. 2017), coupled with reduced biodiversity (Poschlod and Wallis de Vries 2002, Myklestad and Sætersdal 2004, Hilpold et al. 2018).

Certain extensive, traditional land-use systems in Central and Eastern European countries (CEEC) have been affected, but not extremely polarized by the above drivers, or have been revived since the fall of socialism (especially in Transylvania, Romania: Kuemmerle et al. 2009, Mikulcak et al. 2013, Hanspach et al. 2014, Balázsi et al. 2019). Landscape conditions, poor economic opportunities, post-communist agricultural land policies (e.g., land restitution), and, to an extent, respect for and connectedness to the traditional farming mentality (prioritized mainly by older

${ }^{1}$ Research Centre for the Humanities, Institute of Ethnology, Budapest, Hungary, ${ }^{2}$ Valea Rece, Lunca De Jos, Harghita County, Romania, ${ }^{3}$ Centre for Ecological Research, Institute of Ecology and Botany, Vácrátót, Hungary 
generations of farmers) were the main causes of the survival or revival of extensive, traditional land-use systems in Transylvania (Dahlström et al. 2013, Babai and Molnár 2014, Balázsi et al. 2019). Such systems were often sustained in isolated, mainly hilly and mountainous regions (Solymosi 2011, Öllerer 2013, Hanspach et al. 2014, Sutcliffe et al. 2015a, Hartel et al. 2016), where animal husbandry and extensive management of species-rich semi-natural hay meadows and pastures were the most important pillars of local agriculture (Dahlström et al. 2013). The maintenance of speciesrich hay meadows as biodiversity hotspots (Väre et al. 2003, Wilson et al. 2012, Sutcliffe et al. 2015b) and traditional grassland management sustaining high-nature-value grasslands was a cultural and nature conservation objective of European significance, e.g., Natura 2000-network, agri-environment-climate schemes (AECS; Keenleyside et al. 2014, Sutcliffe et al. 2015a, b).

One of the most important elements of extensive, traditional grassland management is the mowing of meadow hay, in particular the decision on the time of mowing (Humbert et al. 2012, Babai and Molnár 2014, Babai et al. 2015). Time of mowing has an effect on the plant species composition of the hay meadows (Blažek and Lepš 2015), invertebrate (Humbert et al. 2010) and vertebrate diversity, e.g., ground-nesting birds (Faria et al. 2016), and on the control of invasive species (Humbert et al. 2012, Szépligeti et al. 2018). For these reasons, the decision on the time of mowing is strictly controlled by numerous, centralized regulations (state- and EU-level legislation). This is despite the fact that drivers determining the choice of the time of mowing, the trade-offs faced by farmers, for example, in relation to the time of mowing (and the resulting compromises they have to make), and the socio-cultural aspects of rural communities and individual farming decisions are all insufficiently studied issues (cf. Kun et al. 2019). Legislation passed without a deeper understanding may have a negative influence on the functioning of the local social-ecological system (Burton and Paragahawewa 2011), and harms local farming interests and values, while conflicts arise between nature conservationists and local farmers (Molnár et al. 2016).

In order to implement and shape regulations that are adapted to the local context, and to increase the cultural and economic sustainability of extensive, traditional farming, it is necessary to gain deeper knowledge of the social-ecological system that is to be regulated, the direct and indirect drivers that impact on the system, and the local understanding of these effects (Burton and Paragahawewa 2011, Hanspach et al. 2014, Babai et al. 2015). We examined all this in a typical cultural landscape maintained by a small-scale farming community living in the Gyimes region (Eastern Carpathians, Transylvania, Romania), as an ideal socialecological model with an extensive, traditional grasslandmanagement system, which has experienced substantial ecological, social, cultural, economic, and political changes in recent years.

Our objectives were to examine the following:

1. the local understanding of the indirect and direct drivers determining the time of mowing of hay meadows and of the change in the time of mowing, in three time periods from the second half of the 20th century until the present day,

2. the local understanding of the trade-offs and compromises related to the time of mowing and to the quality and quantity of hay,

3. the change in the informal system of social institutions related to mowing (and to the time of mowing).
We emphasize the escalating complexity of interactions between direct and indirect drivers, and social-ecological systems operating extensive, traditional land management in a CEECregion, where small-scale farmers face serious difficulties. We strove to highlight the vulnerability of social-ecological systems and small-scale farming, and to warn of the impracticalities of the regulatory environment.

\section{METHODS}

\section{Study area}

We conducted our research in the Gyimes (in Romanian: Ghimeş) region of Eastern Transylvania, in the settlement of Gyimesközéplok (Lunca de Jos) - Hidegségpataka (Valea Rece), N 46.3722 ${ }^{\circ}$-E $25.5724^{\circ}$, Eastern Carpathians, Romania (Fig. 1). The study area covered approximately $90 \mathrm{~km}^{2}$ in a mountainous cultural landscape (800-1400 m a.s.l.; Fig. 2a-d). The total population of the studied settlement is 2340 people (Erdélystat Statistics, http://statisztikak.erdelystat.ro/adatlapok/gyimeskozeplok/1422? fbclid=IwAR08YYD8YoQmpWy0A-S8CKMZXAa743VlqQ1Bqif1f_n2kXMT-TRAgtxgAyY). The population has been relatively stable since the 1950s (Ilyés 2007). Semi-subsistence mountain agriculture is typical in the studied community, whose main pillar is dairy farming. According to our estimates, around $95 \%$ of families are involved in this form of agriculture, either as full-time farmers or in addition to a different type of main occupation. The average size of farms in Gyimes is 3.8 ha (Sólyom et al. 2011).

Fig. 1. The geographical location of the study area in the Eastern Carpathians, Romania. Maps were prepared using ArcGIS.10.1 (ESRI), Natural Earth open layers (https://www. naturalearthdata.com/downloads/).

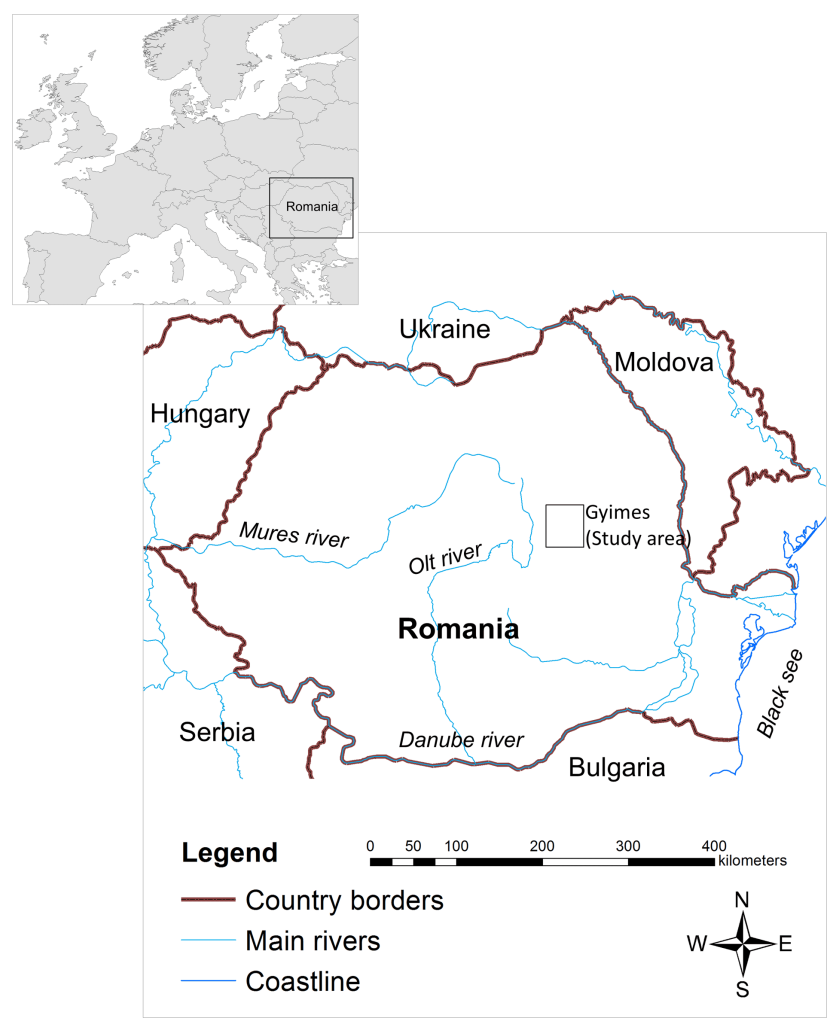


Fig. 2. (a) The studied settlement: Valea Rece in the valley bottom, along the stream. The houses in the settlement are scattered, arable fields and inner hay meadows can be found among the houses. Photo: Dániel Babai. (b) Inner hay meadows in the valley bottom and on the foothills around the settlement are manured and more intensively used than outer hay meadows. Abandoned arable fields are on the slopes. Photo: Dániel Babai. (c) Extensively managed, extremely species-rich mountain hay meadows (outer hay meadows) are mown once a year, and the hay is stored in small buildings on the hay meadows and transported home only in the winter. Photo: Dániel Babai. (d) An extensively managed outer hay meadow provides habitat for many species in the long term. Photo: András Kelemen.

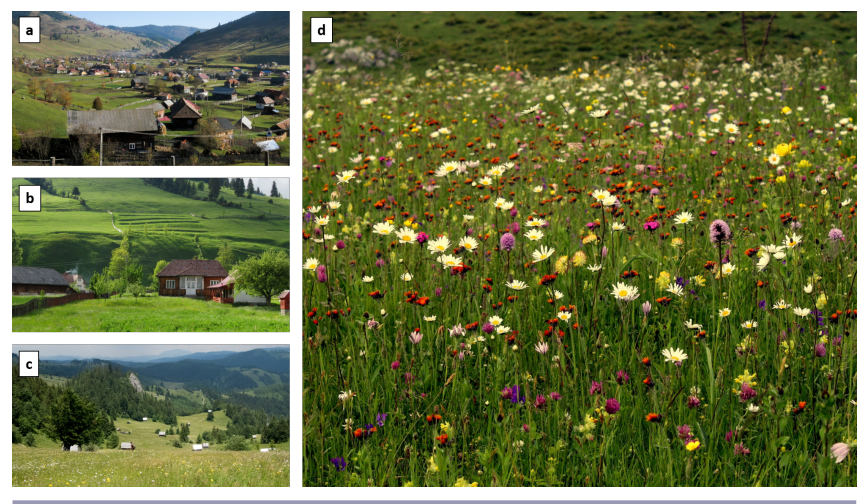

The climate is montane/boreal, with a mean annual temperature of 4-6 ${ }^{\circ} \mathrm{C}$ and annual precipitation of 700-1200 mm (Nechita 2003, Pálfalvi 2010). Because of the landscape and climate conditions, cattle are kept indoors for approximately seven months of each year, consuming, according to the estimates of local farmers, approximately $2.5-3$ tonnes of fodder per animal unit (mainly fibrous hay) each winter. For this reason, grassland management in the Gyimes region is optimized chiefly for the quantity and quality of the hay (Babai and Molnár 2014). Hay is grown on semi-natural meadows developed on the site of former spruce forests (acidophilous Picea abies dominated forests; Babai et al. 2014). The study area is characterized nowadays by $29.4 \%$ forest cover, $65.6 \%$ grasslands (hay meadows and pastures), $1.1 \%$ arable land, and $3.9 \%$ other uses, e.g. built environment (Erdélystat Statistics, http://statisztikak.erdelystat.ro/adatlapok/ gyimeskozeplok/1422?fbclid=IwAR08YYD8YoQmpWy0AS8CKMZXAa743VlqQ1Bqif1f n2kXMT-TRAgtxgAyY).

High nature value semi-natural grasslands are mostly species-rich mesophilous grasslands (Trisetum flavescens hay meadows), highly diverse mountainous acidofrequent grasslands (Festuca rubra hay meadows), and species-rich Nardus swards, which local farmers use as hay meadows or as pastures (Babai and Molnár 2014). Based primarily on their spatial location, and on the type or intensity of management, farmers in Gyimes distinguish between three types of hay meadows: inner (i.e., inlying) valleyfloor meadows, inner (i.e., inlying) foothill meadows, and outer (i.e., outlying) mountain hay meadows (Fig. 3; Babai and Molnár 2014, Kun et al. 2019). Each type has its own distinct vegetation and species composition, and these significant differences are clearly perceived by local farmers (Babai and Molnár 2016, Kun et al. 2019). Until recently, the extensive and traditional grassland management in Gyimes relied largely on the physical power of humans and draft animals, with mechanization mostly occurring in the form of single-axle mower machines (Babai and Molnár 2014). The 2010s also saw the appearance of second-hand fingerwheel hay rakes and self-loading hay wagons (Fig. 4a-f).

Fig. 3. Local farmers distinguish between three types of hay meadows, based primarily on their spatial location in the valley and on mountain slopes. Photo: Dániel Babai.

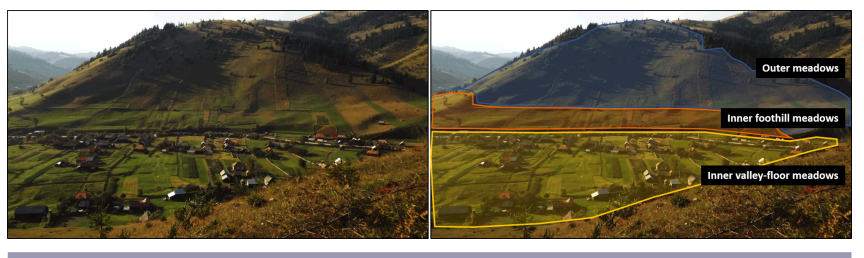

Fig. 4. (a) Mowing kaláka (informal institution of collaborative, communal haymaking) was typical until about the early 2000s. Photo: Marianna Biró. (b) Mowing kaláka was an important social event as well. Relatives, neighbors, friends, men and women, different generations worked together at these events. The second author of the paper is in the photo, sitting on the left of the image. Photo: Marianna Biró. (c) Hand mowing by scythe is still present partly because of the steep slopes where mechanization is impossible, and partly because of the increased amount of financial support in agri-environmentclimate schemes for hand mowing. Photo: Ábel Molnár. (d) Single-axle, motorized mower machines ensure the continuity of mowing in the region. Photo: Ábel Molnár. (e) Mechanization of haymaking is more and more common (finger-wheel hay rakes appeared in the last couple of years). Photo: Dániel Babai. (f) Self-loading hay wagons, so-called "Ladewagens", are more and more common in the valley because of increasing income from abroad earned by younger generations. Photo: Dániel Babai.
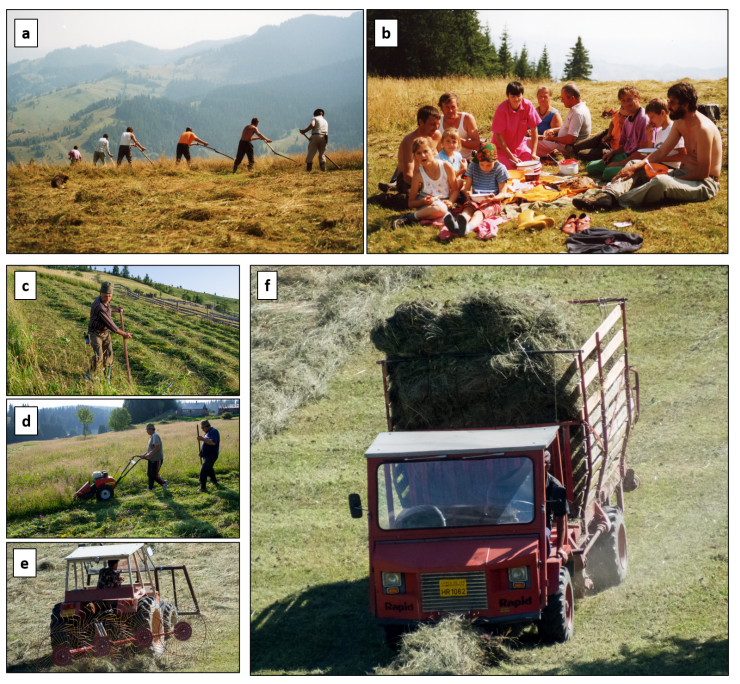


\section{Historical drivers affecting grassland management since the 18th century}

The history of the land-use that significantly affected the vegetation of the studied cultural landscape started in the second half of the 18 th century, when the previously almost completely forested area was transformed by the first settlers into a grasslandforest mosaic within a short period of time (Ilyés 2007). Following the development of the cultural landscape (and lasting until 1950), mostly informal social institutions (e.g., order of inheritance) and demographic (population increase) drivers led to the fragmentation of the hay meadow parcels and in parallel with this to the partial intensification of grassland management (Ilyés 2007, Babai et al. 2014). This intensification was limited by the geomorphology of the landscape and by the poor economic potential, so grassland management remained extensive (Babai et al. 2014, Kun et al. 2019).

Significant new external governance and economic drivers that influenced the landscape structure and biodiversity began to appear from the 1950s onwards (cf. Báldi and Faragó 2007, Hanspach et al. 2014, Sutcliffe et al. 2015b, Balázsi et al. 2019). In the socialist period, the otherwise general transformation of agriculture (collectivization) was only partly implemented in the mountainous regions of Romania, including Gyimes (see, e.g., Kuemmerle et al. 2009, Iancu and Stroe 2016): while the forests and pastures were nationalized, the hay meadows remained privately owned, so their management changed little (cf. Huband and McCracken 2011, Lieskovský et al. 2014). An economic driver also emerged: new work opportunities became available (at the administrative urban center of the region), mainly in industry, so farming became a secondary activity for many families. Nevertheless, the operation of extensive, traditional grassland management was continuous, and farming as a subsistence activity remained highly important.

After the collapse of socialism (1989), the land restitution process and the transition toward a free market-oriented economy resulted in significant social and economic changes (loss of workplaces, renewed importance of agriculture, reappearance of semi-subsistent smallholder farms; cf. Kuemmerle et al. 2009, Mikulcak et al. 2013, Hanspach et al. 2014). Even these changes had negligible impact on hay-meadow management.

However, in 2007, after Romania acceded to the European Union, the legal status of the study area changed, as it was incorporated into the Natura 2000 network (in 2011) as a Site of Community Importance (ROSCI0323 - 59641 ha). Furthermore, a new system of agricultural regulation was introduced within the framework of the EU Common Agricultural Policy (CAP), which aims to reduce the environmental impact of agriculture by providing compensatory payments in exchange for complying with conservation regulations in subsistence farming (AECS; Science for Environment Policy 2017). The most important segments of this scheme in Romania were the single area payment available to all applying farmers (Pillar 1) and, optionally, the payment for agricultural practices beneficial to the climate and the environment (Pillar 2; cf. Mikulcak et al. 2013). These fundamental changes and reforms profoundly influenced extensive grassland-management practices (cf. Mikulcak et al. 2013, Babai et al. 2015).
Despite the recent socioeconomic and regulatory changes, species-rich mountain hay meadows in Gyimes are still managed for subsistence or for family profit by local farmers, not for nature conservation. Most of the local grassland-management practices are in congruence with the goals of the nature conservation regulations, e.g., intensity of use, organic fertilizers, and low impact machinery (Babai et al. 2015). Only a few, but essential elements of the management system, e.g., first date of time of mowing is 1 July, are seriously and negatively affected. These regulations were developed without an adequate understanding of the local ecological and socioeconomic contexts and local farmers' interests (cf. Burton and Paragahawewa 2011, Babai et al. 2015). Local farmers, however, accept the regulations (although knowledge of the exact rules is generally low) in return for the financial support offered by the schemes to decrease the economic vulnerability of their small-scale farms. The insufficient administrative capacity of local and regional authorities allows the rules to be loosely interpreted. Regional NGOs (PogányHavas Association and Barbara Knowles Fund), as bridging organizations, support the operation of small-scale farms and the objectives of farmers, as well as nature conservation initiatives (cf. Mikulcak et al. 2013). Nonetheless, the difficulties of smallscale farms remain, and have even become more severe in recent years.

\section{Data collection and analysis}

In order to gain insight into the local perception of the direct and indirect drivers and trade-offs affecting the time of mowing and traditional grassland management, particular emphasis was placed on participant observation and on actively participating in "collaborative, communal mowing," known locally as the practice of kaláka ( 105 days in the field, e.g., hand-mowing, aftermath mowing, rotating, covering, transporting hay). Furthermore, we conducted structured and semi-structured interviews $(\mathrm{n}=85)$ and organized focus group discussions $(\mathrm{n}=2$, with six and five participants, respectively) with local farmers (n = 52, mean age: 62.5 ) between 2010 and 2019. Interviewees were chosen using snowball sampling. The main focuses of the questions concerned the extensive, traditional management practices on hay meadows that influence the condition of the hay and shape the vegetation and species composition. We asked about direct and indirect drivers affecting management activities. The classification of drivers was based on the categorization of Intergovernmental Science-Policy Platform on Biodiversity and Ecosystem Services (IPBES), which covers all the direct and indirect drivers involved in operating social-ecological systems (see, e.g., Díaz et al. 2015, Elbakidze et al. 2018). Based on this categorization, we considered the perceived impact of climate change, land-use change, direct exploitation, pollution, and invasive species as direct drivers, while economic, technical, demographic, cultural, and governance drivers affecting socialecological systems were deemed indirect drivers. All the drivers mentioned by the interviewees were grouped into these driver categories. Trade-offs made by local farmers were categorized based on their priorities. We examined the relationships between drivers and trade-offs in three important periods generally accepted in CEEC (e.g., Hanspach et al. 2014, Balázsi et al. 2019): Period 1 (P1): 1950-1990, the period of agricultural collectivization, when post-war changes in extensive mountain 
Table 1. The most important culturally and agriculturally defined indicators of the time of mowing in Gyimes in the three studied time periods (abbreviations: TM: time of mowing, IHM: inner hay meadow, OHM: outer hay meadow, AMM: aftermath mowing, AMG: aftermath grazing, AECS: agri-environment-climate schemes).

\begin{tabular}{|c|c|c|c|}
\hline Criteria / Time period & P1 (1950-1990) & P2 (1990-2007) & P3 (2007-2020) \\
\hline $\begin{array}{l}\text { Main principles behind TM } \\
\text { (phenology) }\end{array}$ & $\begin{array}{l}\text { Seed ripening: allow seed ripening to } \\
\text { ensure long-term yield: "By that time } \\
\text { it's ripened, because it needs to ripen } \\
\text { so that the seed falls back. If we cut it } \\
\text { too early every year, before the seed } \\
\text { was ripe, then there would be less } \\
\text { grass, not as abundant." }\end{array}$ & $\begin{array}{l}\text { Flowering: mowing hay in flower to } \\
\text { ensure high quality hay for livestock }\end{array}$ & $\begin{array}{l}\text { Flowering and AECS regulations: } \\
\text { mowing hay regulated by the CAP } \\
\text { agri-environment-climate schemes }\end{array}$ \\
\hline TM / public holidays / IHM & $\begin{array}{l}22 \text { July (feast day of St. Mary } \\
\text { Magdalene) until the } 1970 \text { s }\end{array}$ & $\begin{array}{l}\text { End of June ( } 24 \text { June-feast day of St. } \\
\text { John) }\end{array}$ & $\begin{array}{l}\text { Earlier than the end of June ( } 24 \text { June- } \\
\text { feast day of St. John) }\end{array}$ \\
\hline TM / public holidays / OHM & $\begin{array}{l}20 \text { August (feast day of King St. } \\
\text { Stephen) until the } 1970 \text { s }\end{array}$ & Middle of July & Middle of July \\
\hline TM / public holidays / AMM & End of September until the 1970 s & mid-August & mid-Au \\
\hline TM / public holidays / AMG & Beginning of September & Second part of August & Second part of August \\
\hline TM / phenological state / IHM & \multirow{2}{*}{\multicolumn{3}{|c|}{$\begin{array}{l}\text { - Poaceae-species (seed ripening in P1, flowering in P2, P3): "the grasses show best of all if the hay is ripe, when the } \\
\text { tops are all red."; } \\
\text { - Sinapis arvensis (flowering); } \\
\text { - Tragopogon orientalis (after flowering); } \\
\text { - Onobrychis viciifolia (after flowering): "people really paid attention to common sainfoin, and they would never do the } \\
\text { mowing while it was still flowering."; } \\
\text { - Trifolium spp. (primarily T. alpestre and T. pannonicum) (after flowering): "when it has lost its flowers, then you can } \\
\text { start mowing."; } \\
\text { - Origanum vulgare (flowering): "it grows sooner and gets diseased, people mow those areas earlier."; } \\
\text { - Leucanthemum vulgare (after flowering): "when the marguerite starts to lose its flowers, that's when those grasses } \\
\text { need to be mown."; } \\
\text { - Rhinanthus angustifolius (after flowering).; }\end{array}$}} \\
\hline TM / phenological state / OHM & & & \\
\hline
\end{tabular}

agricultural systems were implemented throughout CEEC; Period 2 (P2): 1990-2007, the period when the late socialist and post-socialist changes clearly affected the human communities and the land-use systems of traditional mountain agrarian landscapes (Hanspach et al. 2014, Tudor 2015); Period 3 (P3): 2007-present, following EU accession, new governance drivers manifested themselves, triggering radical social and economic changes.

All the interviews were conducted by, and focus group discussions were organized by the first author (in Hungarian). The interviews were conducted in accordance with the International Society of Ethnobiology (ISE) Code of Ethics (ISE 2006) and the recommendations of the General Data Protection Regulation (GDPR). Interviewees were informed in advance about the aims of the research and that the research would be published. Prior informed consent was obtained for making the voice recordings (73 hours of recordings).

Interview data were transcribed verbatim (data were illustrated with the translations of verbatim thoughts quoted from local farmers), and arranged in tables using Excel software, according to the salient topics raised by interviewees. These topics were coded, categorized (Ryan and Bernard 2003), and finally analyzed based on the local perception of local farmers about drivers and trade-offs. Of course, the theoretical framework and coding simplified the complexity of the studied social-ecological system, but because of the long-term nature of our research project (2004-), with the help of the second author, who is a knowledgeable, middle-aged farmer from the local community with whom we have collaborated for the last 15 years, we hope we were able to consider all the locally important contextual aspects. All the considered drivers and trade-offs were discussed in detail with the second author.

\section{RESULTS}

Local understanding of the interacting direct and indirect drivers that affect the time of mowing

The time of mowing was traditionally linked to specific public holidays on the calendar and to the phenological stage of the vegetation (Table 1). The time of mowing and the whole system of hay meadow management was influenced by numerous direct and indirect drivers and changed significantly in all three of the periods studied (Table 2, Figs. 5, 6). Certain drivers directly affected the vegetation, and thus the time of mowing (e.g., climate change, change in the intensity of land use), while other drivers had an impact on the socioeconomic context (e.g., intensification, mechanization).

Local farmers regarded the following drivers as the most important: (1) during P1, the cultivation of cereal crops gradually came to an end, and half of the fields were turned into grasslands; manuring of the grasslands also became possible. This resulted in the vegetation developing more quickly, so mowing could be done earlier in the year. (2) Because of the more intensive management of the grasslands, more and more farmers abandoned the practice of springtime grazing on the hay meadows. This also contributed to the vegetation maturing sooner and therefore to earlier mowing. The process was accelerated further by (3) climate change: (3a) the reduced predictability and quantity of peak precipitations in June; (3b) 
Table 2. Direct and indirect drivers in Gyimes (driver categories are based on Elbakidze et al. 2018). Time periods: P1: 1950-1990, P2: 1990-2007, P3: 2007-2019. Daggers ${ }^{\dagger}$ indicate drivers that directly affect the ripening of the vegetation. Other drivers influence further elements of the social-ecological system affecting the time of mowing. Frequency (frequency of mentions): F: frequently mentioned, M: mentioned to a medium extent, R: rarely mentioned. Impact of the drivers: advances (A) or delays (D) the time of mowing; indirectly impacting drivers (InD).

\begin{tabular}{|c|c|c|c|c|}
\hline A) Direct drivers & $\mathrm{Fr}$ & A-D & Time period and explanation of local context & Farmers' opinions \\
\hline $\begin{array}{l}\text { A1. Climate change: average } \\
\text { temperature }\end{array}$ & M & A & $\begin{array}{l}\text { P1: relatively stable average temperature (no } \\
\text { perceivable trends) } \\
\text { P2 - P3: Increasing daily temperature } \\
\text { extremities and increasing monthly average } \\
\text { temperature }^{\dagger}\end{array}$ & $\begin{array}{l}\text { "If only we didn't have these warm periods of } 30 \text { degrees. When it's } \\
\text { warm for a week, then the thin, stony soil on the mountainsides gets } \\
\text { so hot that it bakes the roots." }\end{array}$ \\
\hline $\begin{array}{l}\text { A2. Climate change - } \\
\text { precipitation patterns }\end{array}$ & $\mathrm{R}$ & A & $\begin{array}{l}\text { P1: Regular precipitation peak in June } \\
\text { P2 - P3: Increasing unpredictability of } \\
\text { precipitation and decreasing amount of rain in } \\
\text { June }\end{array}$ & $\begin{array}{l}\text { "Yes, there has been no rain for a couple of years now and (the hay) } \\
\text { is getting ripe now because the weather is too dry." }\end{array}$ \\
\hline $\begin{array}{l}\text { A3. Climate change: } \\
\text { changing seasons }\end{array}$ & $\mathrm{F}$ & A & $\begin{array}{l}\text { P1: Relatively standard seasons } \\
\text { P2 - P3: Earlier start of spring }\end{array}$ & $\begin{array}{l}\text { "The climate has changed so much that we have to do the mowing } \\
\text { everywhere one month earlier. Somehow spring arrives earlier, the } \\
\text { grass grows sooner, so we have to start mowing, because the grass is } \\
\text { ripe enough to be cut." }\end{array}$ \\
\hline $\begin{array}{l}\text { A4. Climate change: extreme } \\
\text { weather events }\end{array}$ & $\mathrm{R}$ & A & $\begin{array}{l}\text { P1 - P2 - P3: Increasing intensity of heavy } \\
\text { rainfall events (storms), which flatten the high } \\
\text { stem manured hay }\end{array}$ & $\begin{array}{l}\text { "If there are storms, then when the grass has grown quickly, the } \\
\text { wind and rain come along and blow it down. If we don't cut it in } \\
\text { time, it rots at the bottom. That's why we have to do the mowing } \\
\text { earlier." }\end{array}$ \\
\hline $\begin{array}{l}\text { A5. Pollution } \\
\text { (agrochemicals, air pollution) }\end{array}$ & $\begin{array}{l}\text { not } \\
\text { relevant }\end{array}$ & - & - & - \\
\hline $\begin{array}{l}\text { A6. Land use change: } \\
\text { transformation of natural } \\
\text { habitats into agricultural } \\
\text { areas or vice versa }\end{array}$ & M & A & $\begin{array}{l}\text { P1: Abandonment of cereal fields, } \\
\text { transformation to hay meadows } \\
\text { P2 - P3: Sale or abandonment of distant } \\
\text { mountain hay meadows, or their conversion } \\
\text { into pastures }\end{array}$ & $\begin{array}{l}\text { "It's not worth farming them, nobody wants them, so they sell them } \\
\text { [hay meadow parcels]. Nobody needs property. We bought it [in the } \\
\text { old days], but now the young people aren't buying, they'd rather } \\
\text { sell." }\end{array}$ \\
\hline $\begin{array}{l}\text { A } 7 / 1 \text {. Land use change: } \\
\text { intensification or } \\
\text { abandonment of agriculture }\end{array}$ & M & A & $\begin{array}{l}\text { P1 - P2 - P3: Intensification of hay meadow } \\
\text { management, e.g., manuring (using organic } \\
\text { manure) }\end{array}$ & $\begin{array}{l}\text { "People manage the hay meadows better, give it more manure, so the } \\
\text { grass grows sooner. Previously we had to manure the fields to have a } \\
\text { good yield, so there was no manure left for the hay meadows. The } \\
\text { grass didn't grow so soon, so it was easier to wait till the end of July. } \\
\text { No manure also meant the grass didn't grow so tall, so it wasn't } \\
\text { blown down by the wind and rain. There was no need to cut it } \\
\text { quickly. But now, if we don't cut it in time, it becomes worthless like } \\
\text { straw, the livestock can't chew it. That's why people do the mowing } \\
\text { sooner, in good time." }\end{array}$ \\
\hline $\begin{array}{l}\text { A } 7 / 2 \text { Land use change: } \\
\text { intensification or } \\
\text { abandonment of agriculture }\end{array}$ & $\mathrm{F}$ & A & $\begin{array}{l}\text { P1: Springtime grazing delays the time of } \\
\text { mowing } \\
\text { P2 - P3: Abandonment of springtime grazing }\end{array}$ & $\begin{array}{l}\text { "You can let them out [i.e., let the livestock out to graze] but this } \\
\text { delays the mowing. They say springtime grazing is good for getting } \\
\text { nicer grass, like with aftermath mowing." }\end{array}$ \\
\hline $\begin{array}{l}\text { A8. Direct exploitation / } \\
\text { extraction: overexploitation }\end{array}$ & $\mathrm{F}$ & $\operatorname{InD}(\mathrm{A})$ & $\begin{array}{l}\text { P1: Seed ripening as primary principle } \\
\text { P2 - P3: Overexploitation: haymaking is too } \\
\text { early, prohibiting seed ripening (decreasing } \\
\text { amount of hay) }\end{array}$ & $\begin{array}{l}\text { "There is less (Trifolium spp.) because we mow the grasslands earlier, } \\
\text { while the clover matures later on, it flowers for a long time. But } \\
\text { nowadays, quick as a flash it's cut, the sooner the better. And then } \\
\text { we wonder why there's no hay. Well, the seeds need to fall back onto } \\
\text { the ground, and then there would be hay the next year as well. If you } \\
\text { cut the hay meadows too early every year, then you'll be waiting in } \\
\text { vain [for a good yield], because the ripe seeds can't fall back, so there } \\
\text { will be no crop." }\end{array}$ \\
\hline $\begin{array}{l}\text { A9. Invasive alien species: } \\
\text { deliberate or unintentional } \\
\text { introduction }\end{array}$ & $\begin{array}{l}\text { not } \\
\text { relevant }\end{array}$ & - & - & - \\
\hline B) Indirect drivers & & Fr / A-D & Time period and explanation of local context & Farmers' opinions \\
\hline $\begin{array}{l}\text { B1. Economic processes, } \\
\text { goods and services (e.g., } \\
\text { processing, manufacturing, } \\
\text { distributing, consuming) }\end{array}$ & $\mathrm{R}$ & $\operatorname{InD}(\mathrm{A})$ & $\begin{array}{l}\text { P1 Gradual abandonment of extensive } \\
\text { cultivation of cereals / new work opportunities } \\
\text { (industry) } \\
\text { P2 Investments: extensive practice is conserved } \\
\text { because of a lack of capital / loss of } \\
\text { workplaces } \\
\text { P3 Investments: income from CAP subsidies } \\
\text { and Western European employment }\end{array}$ & $\begin{array}{l}\text { "The old can't farm any more, the young don't really want to, } \\
\text { because they say it's not worth it for that money. The income is too } \\
\text { little, and you need money to support a family. Farming stops you } \\
\text { from going hungry, but it's a poor source of money, because even at } \\
\text { state level it doesn't get enough support." }\end{array}$ \\
\hline $\begin{array}{l}\text { B2. Demographic: human } \\
\text { population development } \\
\text { (size, age structure) }\end{array}$ & M & $\operatorname{InD}(\mathrm{A})$ & $\begin{array}{l}\text { P1: Relatively stable local population } \\
\text { P2: Ageing of the local community } \\
\text { P3: Ageing of the local community and } \\
\text { outward migration of younger generation }\end{array}$ & $\begin{array}{l}\text { "Nowadays the young people don't really go in for farming, they } \\
\text { leave for other professions or go abroad. The old can't do } \\
\text { everything, so they abandon farming. In } 1961 \text { we used to have five } \\
\text { [head of cattle] in the barn. Now we don't have a single one. My son } \\
\text { also worked in a place which meant it was impossible [to practise } \\
\text { farming]. His wife taught in a school, and so they had no time for } \\
\text { farming, and last year they sold their livestock." }\end{array}$ \\
\hline
\end{tabular}




\section{B3. Technological innovations}

B4. Governance: formal or informal multi-stakeholder processes

B5. Cultural drivers: social processes shaping attitudes, behavior, values, beliefs, norms
A

D

D

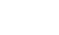

P1: Poor economic condition for development P2: P3 Mechanization: mower machines etc.

P1 - P2: Privately owned hay-meadow parcels P3: CAP - agri-environmental subsidies directly regulating time of mowing (mandatory start of mowing: 1st of July)

M A P1: Relatively stable cultural background P2 - P3: Loosening of social norms and changing value systems of generations and changes in mentality
"Nowadays people have mower machines, which cut the hay in an instant, and then it's gathered up and everything is nicely over and done with."

"Now they make you sign a contract not to do the mowing before 1 st of July. And if you get support for the inner hay meadows, you can't cut the grass there before 1st of July. They give support, but now they ban early mowing, so that the grass seed will fall back to the soil. But by that time [the hay] has all gone yellow, it's overripe. It gets too hot, that's the problem. It's so warm these days that it gets baked through."

The loosening respect for tradition: "I don't know how ripe the hay got in the old days [before WWII], but that was the fashion then, the custom. Now it's cut earlier, everybody wants to get the job done as soon as they can. In the past they didn't cut the grass early. The old folk used to wait for the seed to ripen and fall, so there would be good growth the following year too. Now though, the youngsters mow the hay with all their machines in an instant, they can cut so much in one day that all the haymaking is ready in just two or three days."

The "neighbor effect": "We have to hurry up with the haymaking. We can't be left behind. You know, when the grass is young it's really good, has a higher nutritional value, but like this you are destroying the grass in your own area... For a long time, you only reap, but you don't sow, and then suddenly you can't even reap. Nowadays everyone does the mowing early, and if the neighbor has mown his grass, then I will too - that's how it works." the increasingly early arrival of spring; and (3c) increases in the summer daytime maximum temperature and the number of hot days in summer. Thanks to manuring and the cessation of springtime grazing, the grass stems grew taller and were more easily blown down because of (3d) the increasingly intense and more extremely distributed rainfall patterns. This also shifted the time of mowing to an earlier date. By $\mathrm{P} 2$, the time of mowing on inner hay meadows had shifted to the end of June (24 June-feast day of St. John), and on outer hay meadows to the middle of July. Aftermath mowing only took place on inner hay meadows, from the end of September during P1, and from the middle of August during P2 (Figs. 5, 6). The trend continued during P3, with mowing taking place increasingly earlier in the year (Fig. 5). During P3, besides the impacts continuously advancing the time of mowing, the regulations imposed by the CAP agrienvironment-climate scheme (AECS) exerted the opposite effect, resulting in delaying the time of mowing.

\section{Trade-offs and compromises when deciding on the time of mowing}

Local farmers evaluated numerous factors when deciding on the optimal time of mowing (Table 3, Appendix 1, Fig. 7). The most important were (1) the proper quality of hay collected, from an economic and livestock welfare point of view (early-mown hay); (2) long-term yield stability by ensuring seed ripening (late-mown hay); and (3) considering centralized governance drivers, especially the regulations of CAP in order to qualify for financial support of agri-environment-climate schemes (rigid deadline of mowing: 1 July). When deciding on the best time for mowing in any given year, the locals also took other factors into consideration, such as (1) other summertime agricultural tasks (organizing labor within the family); (2) the availability of mechanized mowers and/or hand-mowing capacity; and (3) the basic features of the given landscape or site (e.g., exposure: "it also depends, if it's directly exposed to bright sunshine, then mowing is done earlier, otherwise the grass gets too hot and the hay goes bad in the extreme heat. If it's on the north side, then that can be left a little longer, because the sun doesn't shine so hard there"). Other factors considered were (4) the amount of manuring done to the site, (5) whether or not the meadows were used for springtime grazing, (6) the possibility of aftermath mowing in autumn, (7) the dominance of different plant functional groups (Poaceae, Fabaceae, Forbs), or (8) the dominance of key species (e.g., Onobrychis viciifolia; "there are many different plant species, and surely some are harmed by early mowing, while others benefit from it"). Old traditions of the families and individual decisions based on experience of local farmers also determined the time of mowing in any given year ("Everyone does things slightly differently"; "[one year] I mow that part earlier, the next year I mow it later, so I change [the order]").

\section{Complex changes: decaying informal social institutions}

The increased number of drivers and related trade-offs in P3 caused a suboptimal situation regarding the time of mowing, based on the understanding of local farmers (primarily because of climate change). Hay-meadow parcels contracted in agrienvironment-climate schemes are not allowed to be mown before 1 July. At the same time, extreme maximum daytime temperatures in early summer and the increasingly frequent absence of precipitation in June accelerated the ripening of the vegetation. This meant that the time of mowing on inner hay meadows subject to agri-environment-climate schemes was economically unfavorable.

In this situation, it became essential for every farmer to commence mowing immediately and individually after 1 July, meaning that farmers were unable to help each other. The time constraints made it impossible for the local farmers to carry on the traditional practice of "collaborative, communal haymaking," known as kaláka, an informal social institution in which family-owned farms helped each other by combining their limited workforces (Fig. 8): "I don't call anyone to help me with my mowing so that 
Fig. 5. The timing of grassland management practices that are important from the point of view of the time of mowing to the annual cycle. The diagram shows the times described as optimal by local farmers but does not show the date of 1st of July, given in the CAP subsidy system.

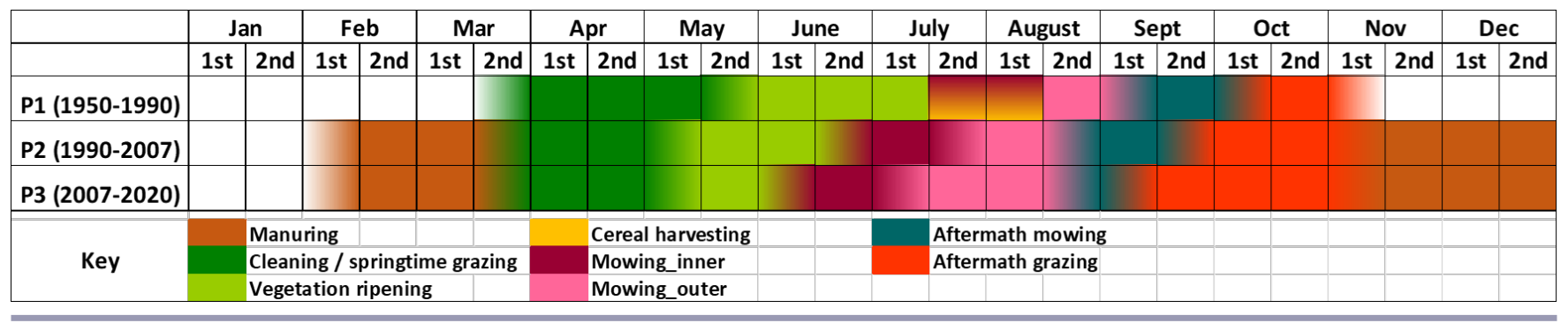

I don't have to help them back, because on my own I can't manage to help everyone back. ... For two days we work on my meadow, and then for two days we do yours. That's how it would go, like in the old days. But no more, now I start mowing, because it's the right time for it, but when it's good for me, then everybody does [their own] ... It's like this because of the weather." In the past, collaborative, communal haymaking shortened the time needed to complete mowing on each given meadow parcel and also reduced the risk of the hay becoming rain-soaked. According to the locals, the abandonment of the haymaking-kaláka as an "adaptive" strategy was also partly the result of the increasing use of mower machines, which significantly reduced the time needed to complete mowing.

\section{DISCUSSION}

Interacting direct and indirect drivers affecting social-ecological systems and the time of hay mowing

Based on the perceptions and understanding of local farmers, extensive, traditional grassland management, especially the timing of mowing, has had to cope with increasing pressures since the 1950s because of the cumulative impact and interactions of direct and indirect drivers. Some of the direct drivers affected the phenological phases of the vegetation, which contributed to changes in the optimal and actual time of mowing. Other drivers only impacted on the socio-cultural and economic context of the time of mowing. According to the local farmers, the direct drivers (climate change and land-use change) have so far not irreversibly affected the operation of extensive, traditional land-use systems, but socioeconomic and political interventions have placed these systems under considerable pressure (cf. Tyler at al. 2021). The gradually changing mentality of younger generations, together with rigid national and EU-level regulations, e.g., AECS, often unreasonably limit the individual decisions of local farmers, for example, by not taking into account the local ecological (e.g., the weather effects of a given year) and socio-cultural context (e.g., informal social institutions, like traditional ecological knowledgebased grassland management; Dahlström et al. 2013). These limitations have a negative impact on the operation of small-scale farms, despite the financial support the farmers receive (Dahlström et al. 2013, Mikulcak et al. 2013, 2015, Iancu and Stroe 2016). This mismatch may seriously jeopardize not only the survival of extensive, traditional grassland management and long-term yields (by harming grassland regeneration), but also the biodiversity of these mountain grasslands in general
(Humbert et al. 2012, Hanspach et al. 2016, Kun et al. 2019). However, it is also important to note that the impact of changing weather patterns on agricultural practices is indisputable and was an important part of the public discourse in the studied local community. Although mountain regions worldwide are increasingly affected by climate change, the perceptions of local communities and the complex consequences of changing weather patterns on the local social-ecological systems are still rarely studied (Reyes-Garcia et al. 2016).

Our data indicated an increasing complexity and interaction of drivers. We argue that the cumulative effects of drivers threaten the adaptive capacity of the local management system (cf. Hanspach et al. 2014), and slowly eliminate essential factors, such as farmers with thorough traditional ecological knowledge, with previously typical social norms, and with a farming mindset that strives for self-sufficiency (cf. Balázsi et al. 2019).

\section{The local understanding of trade-offs to navigate among interacting drivers}

Because of the increasing cumulative effects of drivers, local farmers in Gyimes are forced to navigate between a number of trade-offs when deciding on management practices (in our case: the time of mowing). It has become almost impossible to reckon with all the ecological, economic, socio-cultural, and political/ nature conservation factors (cf. Iancu and Stroe 2016). Meanwhile, the agricultural priorities of local farmers have also changed: although ensuring seed ripening for long-term yield stability was the primary goal among farmers in the first period, in later periods the quality of hay increased in importance. Consequently, changing priorities and current drivers have culminated in a single, but challenging decision: local farmers in Gyimes have to weigh up agricultural factors (livestock welfare, hay that is mown at the optimal phenological stage) against the amount of financial support they receive from AECS in order to maintain adaptive capacity and the generally poor economic viability of their small-scale farms (cf. Tudor 2015, Iancu and Stroe 2016).

This adaptation has also caused the gradual disappearance of an informal social "barter" institution (kaláka, collaborative, communal mowing) that previously optimized the workforces of small-scale farms and fostered social cohesion. This informal institution was an important form of cooperation within grassland management that also played a role in shaping social relationships (social capital) and building cohesion in the 
Fig. 6. The direct and indirect drivers influencing the time of mowing. The colors of the arrows: grey arrows indicate delays to the time of mowing, whereas black arrows indicate advances to the time of mowing. The colors of the "driver boxes" show the periods examined: light grey means P1, dark grey means P2, black means P3, while boxes shaded in transitions of two colors refer to drivers found in two periods. The white boxes refer to drivers found in all three of the periods examined

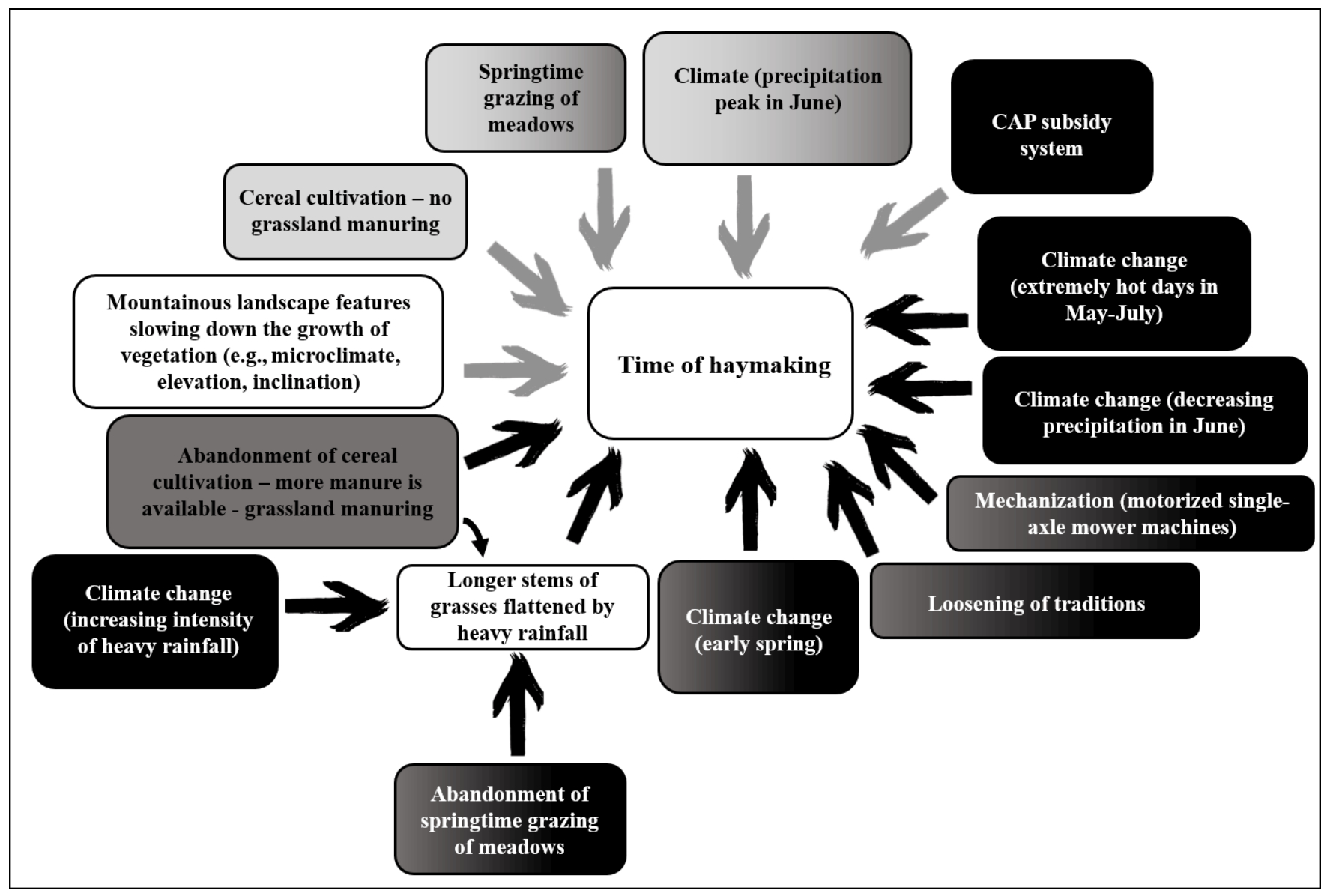

community (cf. Burton and Paragahawewa 2011, Burton and Schwarz 2013, Mikulcak et al. 2013, de Krom 2017).

Recommendations to develop more adequate agri-environmentclimate schemes

The drivers and trade-offs documented in our study are not specific to Gyimes, but exist everywhere in Transylvania, even in other regions of CEEC, and make it more difficult for extensive, traditional land-use systems to survive (Lieskovský et al. 2014, Žarnovičan et al. 2020). AECS as an optional political factor could help to mitigate some of these undesirable effects of the harsh socioeconomic environment, especially through a welladapted financial support system targeting small-scale farmers. At the same time there are conflicting points in the regulatory system. The first is the inflexible character of regulations on the time of mowing and on other management practices (Mikulcak et al. 2013, Page et al. 2019). A more rational regulation that loosens the restrictions on when mowing can be carried out, e.g., by taking the year-effects of weather conditions, altitude etc. into account, could be more readily accepted locally (whereas the present restrictions often discourage farmers from participating in the schemes). A more flexible regulation could ensure the operation of the parcel-level land-use microdiversity as well, which is favorable for the high quality of hay in terms of the phenological state of the vegetation and is also favorable for biodiversity (Kun et al. 2019). The second point is the eligibility criteria related to the minimum area of a meadow parcel for entitlement to AECS ( 0.3 ha in the case of hay meadows). A significant part of the species-rich hay meadows in the study area and in Transylvania cannot meet these criteria (Dahlström et al. 2013, Mikulcak et al. 2013, Iancu and Stroe 2016). Regulation of the time of management practices homogenizes and synchronizes micro-scale land-use diversity, while built-in eligibility criteria for minimum area leads to the fusion of parcels. Both phenomena have a strong negative impact on biodiversity (Cizek et al. 2012, Dahlström et al. 2013, Sutcliffe et al. 2015b, Kun et al. 2019). A further important issue is the need for greater income through subsidies and through the increased marketability of high-quality local agricultural products of small-scale farms, which can be crucial for increasing their economic viability, maintaining a production-oriented mentality rather than one that responds solely to the interests of financial compensation (Burton and Paragahawewa 2011), and fostering willingness among younger 
Fig. 7. Increasing number of direct and indirect drivers and trade-offs regarding the timing of mowing on hay meadows in the studied periods since the 1950s in Gyimes, Eastern Carpathians, Romania. Key: green: direct driver-climate change; brown: direct driver-land use change; blue: direct driver-direct exploitation; yellow: indirect drivers-economic, demographic, technological, governance, and cultural drivers

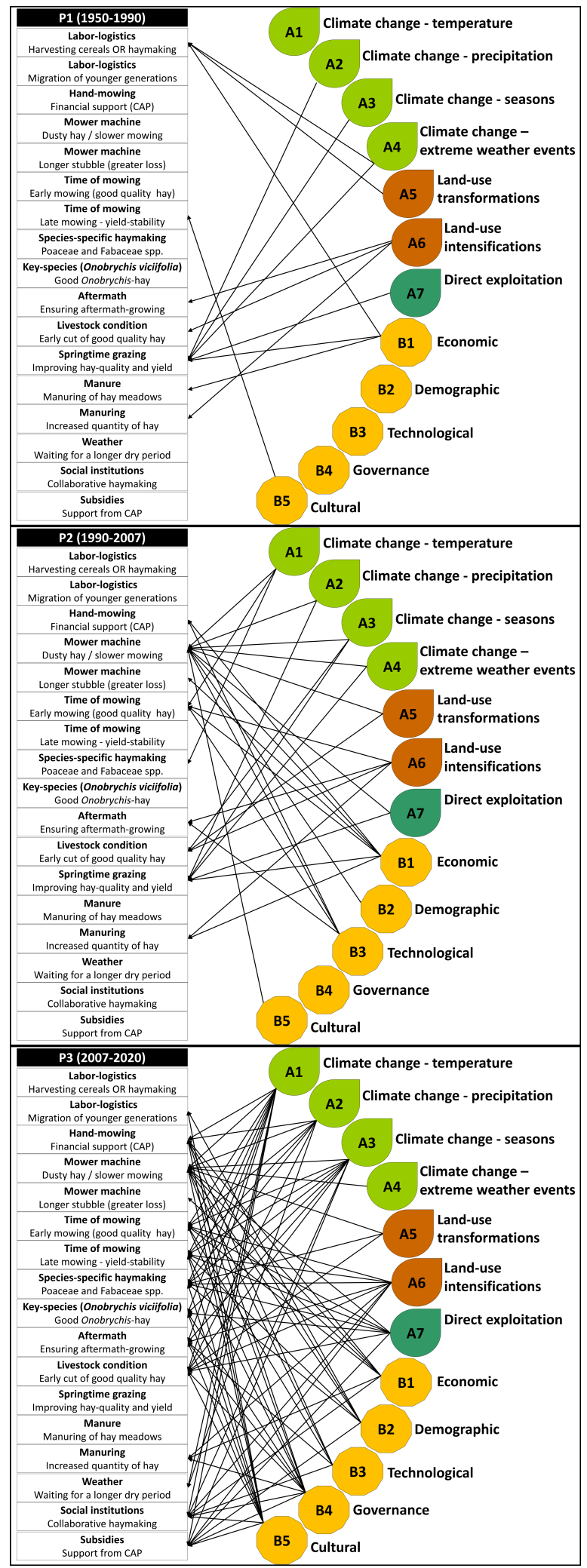


Table 3. Trade-offs made by local farmers in order to define the appropriate time of mowing. Time periods studied (P1: 1950-1990, P2: 1990-2007, P3: 2007-2020). D: direct drivers, ID: indirect drivers.

\begin{tabular}{|c|c|c|c|}
\hline Trade-offs & Time period & Explanation & Affecting drivers \\
\hline (1) Labor logistics \# 1 & $\mathrm{P} 1$ & Harvesting (mowing) of cereals OR haymaking & $\begin{array}{l}\text { D: climate change, land use change } \\
\text { ID: economic }\end{array}$ \\
\hline (2) Labor logistics \# 2 & P3 & $\begin{array}{l}\text { Migration of younger generations and less well- } \\
\text { tended hay meadows OR youth remain: right time } \\
\text { of haymaking, but lack of financial capital }\end{array}$ & $\begin{array}{l}\text { D: - } \\
\text { ID: demographic, cultural }\end{array}$ \\
\hline (3) Hand mowing & $(\mathrm{P} 2), \mathrm{P} 3$ & $\begin{array}{l}\text { More financial support from CAP OR greater risk } \\
\text { of hay damage in rainy weather }\end{array}$ & $\begin{array}{l}\text { D: climate change } \\
\text { ID: economic, demographic, technological, } \\
\text { governance, cultural }\end{array}$ \\
\hline (4) Mower machines \# 1 & $\mathrm{P} 2, \mathrm{P} 3$ & Dusty hay OR slower, harder haymaking by scythe & $\begin{array}{l}\text { D: climate change, land use change, direct } \\
\text { exploitation } \\
\text { ID: economic, demographic, technological, } \\
\text { governance, cultural }\end{array}$ \\
\hline (5) Mower machines \# 2 & $\mathrm{P} 2, \mathrm{P} 3$ & $\begin{array}{l}\text { Longer stubble (greater loss) OR slower, harder } \\
\text { haymaking by scythe }\end{array}$ & $\begin{array}{l}\text { D: - } \\
\text { ID: economic }\end{array}$ \\
\hline (6) Time of mowing \# 1 & $\mathrm{P} 1, \mathrm{P} 2, \mathrm{P} 3$ & $\begin{array}{l}\text { Early mowing: short-term benefit of hay quality and } \\
\text { long-term loss hampering completion of } \\
\text { reproductive cycle OR vice versa }\end{array}$ & $\begin{array}{l}\text { D: climate change, land use change, direct } \\
\text { exploitation } \\
\text { ID: economic, technological, governance }\end{array}$ \\
\hline (7) Time of mowing \# 2 & $\mathrm{P} 1, \mathrm{P} 2, \mathrm{P} 3$ & $\begin{array}{l}\text { Late mowing: long-term stability of the yield and } \\
\text { loss of quality OR vice versa }\end{array}$ & $\begin{array}{l}\text { D: climate change, land use change, direct } \\
\text { exploitation } \\
\text { ID: demographic, governance, cultural }\end{array}$ \\
\hline (8) Aftermath & $\mathrm{P} 1, \mathrm{P} 2, \mathrm{P} 3$ & $\begin{array}{l}\text { Harvesting the hay earlier in order to ensure time to } \\
\text { grow aftermath OR allowing completion of } \\
\text { reproductive cycle }\end{array}$ & $\begin{array}{l}\text { D: climate change, land use change } \\
\text { ID: technological, governance, cultural }\end{array}$ \\
\hline (9) Species-specific haymaking & $\mathrm{P} 1, \mathrm{P} 2, \mathrm{P} 3$ & $\begin{array}{l}\text { Considered species are Poaceae species and some } \\
\text { selected Fabaceae species OR Forbs }\end{array}$ & $\begin{array}{l}\text { D: climate change, land use change, direct } \\
\text { exploitation } \\
\text { ID: demographic, cultural }\end{array}$ \\
\hline (10) Key species & $\mathrm{P} 1, \mathrm{P} 2, \mathrm{P} 3$ & $\begin{array}{l}\text { Onobrychis viciifolia: early mowing harvesting good } \\
\text { Onobrychis hay OR delayed mowing supporting } \\
\text { completion of the reproductive cycle }\end{array}$ & $\begin{array}{l}\text { D: climate change, direct exploitation } \\
\text { ID: governance, cultural }\end{array}$ \\
\hline (11) Livestock condition & $\mathrm{P} 1, \mathrm{P} 2, \mathrm{P} 3$ & $\begin{array}{l}\text { Early cut of good quality hay (milk production) OR } \\
\text { later mowing and seed ripening }\end{array}$ & $\begin{array}{l}\text { D: climate change, land use change, direct } \\
\text { exploitation } \\
\text { ID: governance, cultural }\end{array}$ \\
\hline $\begin{array}{l}\text { (12) Springtime grazing of hay } \\
\text { meadow }\end{array}$ & $\mathrm{P} 1, \mathrm{P} 2$ & $\begin{array}{l}\text { Improving the quality of hay and increasing yield } \\
\text { security but trampling of carefully managed } \\
\text { grasslands OR vice versa }\end{array}$ & $\begin{array}{l}\text { D: climate change, direct exploitation } \\
\text { ID: economic }\end{array}$ \\
\hline (13) Manure & $\mathrm{P} 1$ & Manuring of arable fields OR hay meadows & $\begin{array}{l}\text { D: - } \\
\text { ID: economic }\end{array}$ \\
\hline (14) Manuring & $\mathrm{P} 1, \mathrm{P} 2, \mathrm{P} 3$ & $\begin{array}{l}\text { Increased quantity of hay (aftermath) OR lower } \\
\text { quality (Poaceae dominance) }\end{array}$ & $\begin{array}{l}\text { D: land use change } \\
\text { ID: economic, governance }\end{array}$ \\
\hline (15) Weather & $\mathrm{P} 1, \mathrm{P} 2, \mathrm{P} 3$ & $\begin{array}{l}\text { Waiting for a longer dry period to dry the hay } O R \\
\text { mowing at the right time }\end{array}$ & $\begin{array}{l}\text { D: climate change } \\
\text { ID: - }\end{array}$ \\
\hline (16) Social institutions & P3 & $\begin{array}{l}\text { Collaborative, communal haymaking (kaláka) OR } \\
\text { haymaking at the right time individually }\end{array}$ & $\begin{array}{l}\text { D: climate change, land use change } \\
\text { ID: economic, technological, governance, } \\
\text { cultural }\end{array}$ \\
\hline (17) Subsidies & P3 & Support from CAP OR haymaking at the right time & $\begin{array}{l}\text { D: climate change, land use change, direct } \\
\text { exploitation } \\
\text { ID: demographic, governance, cultural }\end{array}$ \\
\hline
\end{tabular}

generations of farmers to continue at least some of the extensive practices (cf. Mikulcak et al. 2013, 2015, Hanspach et al. 2014). Although small-scale and semi-subsistence forms of agricultural production are considered administratively and economically unsustainable and uncompetitive (Mikulcak et al. 2013), these farmers are recognized by the public and by nature conservation as highly important actors producing high-quality food and maintaining HNV cultural landscapes, diverse ecosystem services, and biodiversity of European significance (Sutcliffe et al. 2015a, b).

Increasing flexibility, changing eligibility, and strengthening the local-product-oriented mentality point to a transition from a centralized and inflexible, action-based form of AECS (regulation of management practices in exchange for financial compensation) to a results-based approach of AECS (paying for biodiversity achievements; Burton and Paragahawewa 2011, in France: Fleury et al. 2015, for a pilot-project in Transylvania see: Page et al. 2019). Such regulatory reforms seem to be greatly preferred in communities where there is still a willingness to continue the existing small-scale, extensive, traditional land-use system, and where the necessary traditional ecological knowledge and cultural values still prevail, like in Gyimes and in many regions of Transylvania (cf. Babai and Molnár 2014, Iancu and Stroe 2016, Hanspach et al. 2016, Ivaşcu et al. 2016). 
Fig. 8. The indirect and direct drivers that caused the practice of "collaborative, communal haymaking" (the so-called kaláka) to come to an end over the last 5-10 years in Gyimes.

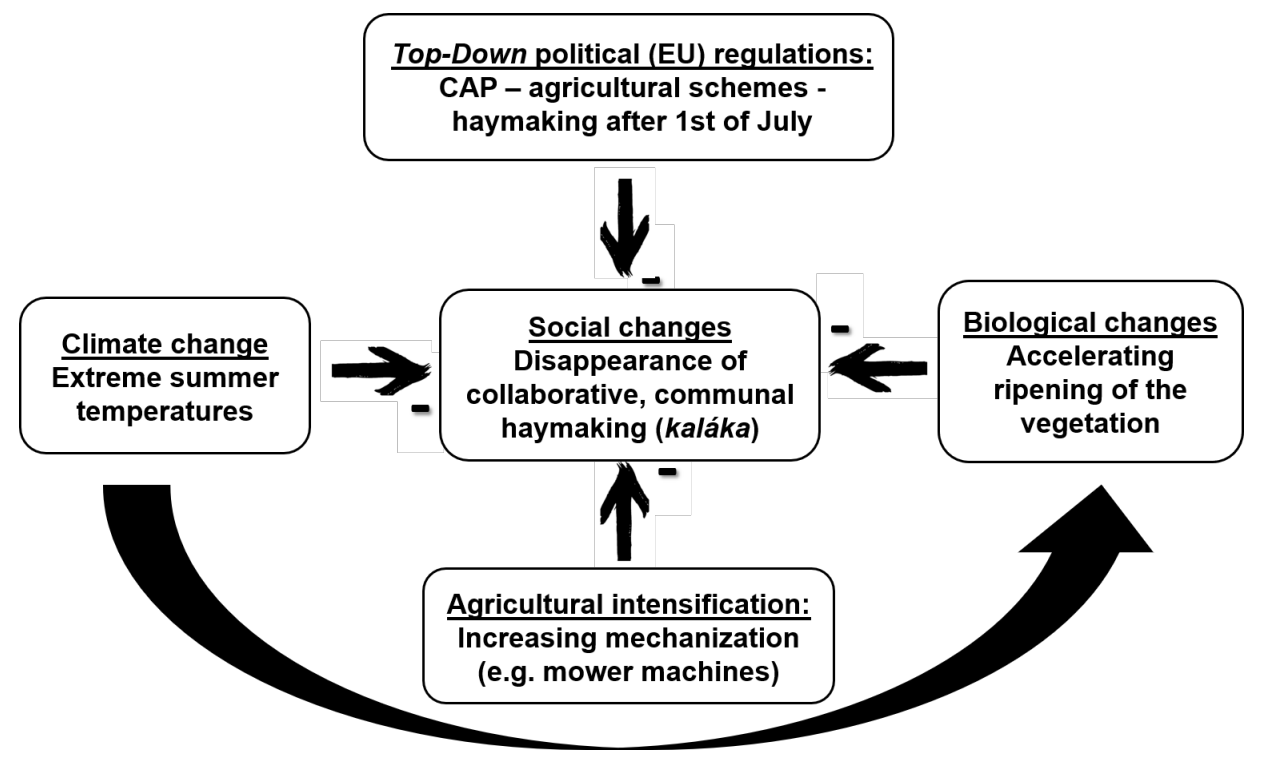

The rarely considered social aspects of extensive, traditional landuse systems (e.g., attitudes of farmers, social norms, farmers' interest in social capital, and status, being a 'good farmer' based on local principles) could attain a better position as a result of this transition (cf. Burton and Paragahawewa 2011, Burton and Schwarz 2013, Sutcliffe et al. 2015a, de Krom 2017). Clearly, the social-ecological systems that still exist that make use of traditional land-use practices built on traditional ecological knowledge deserve special attention and should be encouraged and prioritized by decision makers and by AECS in CEEC (Dahlström et al. 2013, Babai et al. 2015, Molnár et al. 2020), because neither the species-rich semi-natural grasslands nor the mentality of small-scale farmer communities can be restored through the conventional compensation strategies of AECS (Sutcliffe et al. 2015b).

\section{CONCLUSIONS}

We documented an increasing complexity of interacting direct and indirect drivers on traditional land use over the last decades in the studied mountain community. Local farmers found it increasingly difficult to strike the optimal balance when making trade-offs, specifically, in our case, with regard to the time of mowing. Our results suggest that the local community is not far from reaching its adaptive capacity. We argue that more flexible and adaptive agri-environment-climate regulations are needed in order to assure the continuity and ongoing adaptation of this and other Eastern Central European, centuries-old, traditional management systems, which are responsible for creating and maintaining high nature value cultural landscapes.

Responses to this article can be read online at: https://www.ecologyandsociety.org/issues/responses. $\mathrm{php} / 12679$

\section{Acknowledgments:}

We, the authors, would like to express our gratitude to the interviewees for sharing their time and knowledge with us during our research. We express special thanks to Béla Jánó's family for helping with our field work, and we also thank Steve Kane for English translations and revision. Special thanks to the reviewers, whose comments and suggestions greatly improved the earlier versions of the manuscript. Dániel Babai was supported by the MTA Premium Postdoctoral Research Fellowship Program of the Hungarian Academy of Sciences [grant number: PPD008/2017], by the LICCI - Local Indicators of Climate Change Impacts: the contribution of local knowledge to climate change research program under the European Union's Horizon 2020 research and innovation programme (ERC Consolidator Grant No 771056 LICCI), and by the MTA Lendület Program (LENDULET_2020-56). Zsolt Molnár was supported by the project Fine-scale landscape ecology: linking vegetation change with interacting indirect and direct drivers using traditional ecological knowledge and oral history (NKFI K 131837).

\section{Data Availability:}

The data that support the findings of this study are available on request from the corresponding author, DB. The data are not publicly available because they contain information that could compromise the privacy of research participants.

\section{LITERATURE CITED}

Babai, D., and Z. Molnár. 2014. Small-scale traditional management of highly species-rich grasslands in the Carpathians. Agriculture, Ecosystem and Environment 182:123-130. https:// doi.org/10.1016/j.agee.2013.08.018 
Babai, D., and Z. Molnár. 2016. Species-rich mountain grasslands through the eyes of the farmer: flora, species composition, and extensive grassland management. Martor 21:146-170.

Babai, D., Á. Molnár, and Z. Molnár. 2014. Traditional ecological knowledge and land use in Gyimes (Eastern-Carpathians) [Title translated from the Hungarian]. Research Center for the Humanities and Ecological Research Centre, Hungarian Academy of Sciences, Budapest-Vácrátót, Hungary.

Babai, D., A. Tóth, I. Szentirmai, M. Biró, A. Máté, L. Demeter, M. Szépligeti, A. Varga, Á. Molnár, R. Kun, and Z. Molnár. 2015. Do conservation and agri-environmental regulations effectively support traditional small-scale farming in East-Central European cultural landscapes? Biodiversity and Conservation 24:3305-3327. https://doi.org/10.1007/s10531-015-0971-Z

Balázsi, Á., M. Riechers, T. Hartel, J. Leventon, and J. Fischer. 2019. The impacts of social-ecological system change on humannature connectedness: a case study from Transylvania, Romania. Land Use Policy 89:104232. https://doi.org/10.1016/j. landusepol.2019.104232

Báldi, A., and S. Faragó. 2007. Long-term changes of farmland game populations in a post-socialist country (Hungary). Agriculture, Ecosystem and Environment 118:307-311. https:// doi.org/10.1016/j.agee.2006.05.021

Bignal, E. M., and D. I. McCracken. 2000. The nature conservation value of European traditional farming systems. Environmental Reviews 8:149-171. https://doi.org/10.1139/ a00-009

Biró, M., Z. Molnár, D. Babai, A. Dénes, A. Fehér, S. Barta, L. Sáfián, K. Szabados, A. Kiš, L. Demeter, and K. Öllerer. 2019. Reviewing historical traditional knowledge for innovative conservation management: a re-evaluation of wetland grazing. Science of the Total Environment 666:1114-1125. https://doi. org/10.1016/j.scitotenv.2019.02.292

Blažek, P., and J. Lepš. 2015. Victims of agricultural intensification: mowing date affects Rhinanthus spp. regeneration and fruit ripening. Agriculture, Ecosystem and Environment 211:10-16. https://doi.org/10.1016/j.agee.2015.04.022

Burton, R. J. F., and U. H. Paragahawewa. 2011. Creating culturally sustainable agri-environmental schemes. Journal of Rural Studies 27:95-104. https://doi.org/10.1016/j.jrurstud.2010.11.001

Burton, R. J. F., and G. Schwarz. 2013. Result-oriented agrienvironmental schemes in Europe and their potential for promoting behavioural change. Land Use Policy 30:628-641. https://doi.org/10.1016/j.landusepol.2012.05.002

Cizek, O., J. Zamecnik, R. Tropek, P. Kocarek, and M. Konvicka. 2012. Diversification of mowing regime increases arthropods diversity in species-poor cultural hay meadows. Journal of Insect Conservation 16:215-226. https://doi.org/10.1007/s10841-011-9407-6

Dahlström, A., A. M. Iuga, and T. Lennartsson. 2013. Managing biodiversity rich hay meadows in the EU: a comparison of Swedish and Romanian grasslands. Environmental Conservation 40:194-205. https://doi.org/10.1017/S0376892912000458 de Krom, M. P. 2017. Farmer participation in agri-environmental schemes: regionalisation and the role of bridging social capital. Land Use Policy 60:352-361. https://doi.org/10.1016/j. landusepol.2016.10.026

Díaz, S., S. Demissew, J. Carabias, C. Joly, M. Lonsdale, N. Ash, A. Larigauderie, J. R. Adhikari, S. Arico, A. Báldi, A. Bartuska, I. A. Baste, A. Bilgin, E. Brondizio, K. M. Chan, V. E. Figueroa, A. Duraiappah, M. Fischer, R. Hill, T. Koetz, P. Leadley, P. Lyver, G. M. Mace, B. Martin-Lopez, M. Okumura, D. Pacheco, U. Pascual, E. S. Pérez, B. Reyers, E. Roth, O. Saito, R. J. Scholes, N. Sharma, H. Tallis, R. Thaman, R. Watson, T. Yahara, Z. A. Hamid, C. Akosim, Y. Al-Hafedh, R. Allahverdiyev, E. Amankwah, S. T. Asah, Z. Asfaw, G. Bartus, L. A. Brooks, J. Caillaux, G. Dalle, D. Darnaedi, A. Driver, G. Erpul, P. EscobarEyzaguirre, P. Failler, A. M. M. Fouda, B. Fu, H. Gundimeda, S. Hashimoto, F. Homer, S. Lavorel, G. Lichtenstein, W. A. Mala, W. Mandivenyi, P. Matczak, C. Mbizvo, M. Mehrdadi, J. P. Metzger, J. B. Mikissa, H. Moller, H. A. Mooney, P. Mumby, H. Nagendra, C. Nesshover, A. A. Oteng-Yeboah, G. Pataki, M. Roué, J. Rubis, M. Schultz, P. Smith, R. Sumaila, K. Takeuchi, S. Thomas, M. Verma, Y. Yeo-Chang, and D. Zlatanova. 2015. The IPBES conceptual framework - connecting nature and people. Current Opinion in Environmental Sustainability 14:1-16. https:// doi.org/10.1016/j.cosust.2014.11.002

Dorresteijn, I., J. Loos, J. Hanspach, and J. Fischer. 2015. Socioecological drivers facilitating biodiversity conservation in traditional farming landscapes. Ecosystem Health and Sustainability 1:1-9. https://doi.org/10.1890/EHS15-0021.1

Elbakidze, M., T. Hahn, and N. E. Zimmermann. 2018. Direct and indirect drivers of change in biodiversity and nature's contributions to people. Pages 384-569 in M. Rounsevell, M. Fischer, A. Torre-Marin Rando, and A. Mader, editors. The IPBES regional assessment report on biodiversity and ecosystem services for Europe and Central Asia. Secretariat of the Intergovernmental Science-Policy Platform on Biodiversity and Ecosystem Services, Bonn, Germany. https://doi.org/10.5281/ zenodo. 3237428

Faria, N., M. B. Morales, and J. E. Rabaça. 2016. Between and within-year effects of haying on grassland bird populations and spatial dynamics. Agriculture, Ecosystem and Environment 220:193-201. https://doi.org/10.1016/j.agee.2016.01.014

Fischer, J., T. Hartel, and T. Kuemmerle. 2012. Conservation policy in traditional farming landscapes. Conservation Letters 5:167-175. https://doi.org/10.1111/j.1755-263X.2012.00227.x

Fleury, P., C. Seres, L. Dobremez, B. Nettier, and Y. Pauthenet. 2015. "Flowering meadows", a result-oriented agrienvironmental measure: technical and value changes in favour of biodiversity. Land Use Policy 46:103-114. https://doi.org/10.1016/j. landusepol.2015.02.007

Hanspach, J., T. Hartel, A. I. Milcu, F. Mikulcak, I. Dorresteijn, J. Loos, H. von Wherden, T. Kuemmerle, D. Abson, A. KovácsHostyánszki, A. Báldi, and J. Fischer. 2014. A holistic approach to studying social-ecological systems and its application to southern Transylvania. Ecology and Society 19(4):32. http://dx. doi.org/10.5751/ES-06915-190432 
Hanspach, J., J. Loos, I. Dorresteijn, D. Abson, and J. Fischer. 2016. Characterizing social-ecological units to inform biodiversity conservation in cultural landscapes. Diversity and Distributions 22:853-864. https://doi.org/10.1111/ddi.12449

Hartel, T., K. O. Réti, C. Craioveanu, R. Gallé, R. Popa, A. Ioniţă, L. Demeter, L. Rákosy and B. Czúcz. 2016. Rural socialecological systems navigating institutional transitions: case study from Transylvania (Romania). Ecosystem Health and Sustainability 2:e01206. https://doi.org/10.1002/ehs2.1206

Henle, K., D. Alard, J. Clitherow, P. Cobb, L. Firbank, T. Kull, D. McCracken, R. F. A. Moritz, J. Niemelä, M. Rebane, D. Wascher, A. Watt, Y. Young. 2008. Identifying and managing the conflicts between agriculture and biodiversity conservation in Europe - a review. Agriculture, Ecosystem and Environment 124:60-71. https://doi.org/10.1016/j.agee.2007.09.005

Hilpold, A., J. Seeber, V. Fontana, G. Niedrist, A. Rief, M. Steinwandter, E. Tasser, and U. Tappeiner. 2018. Decline of rare and specialist species across multiple taxonomic groups after grassland intensification and abandonment. Biodiversity and Conservation 27:3729-3744. https://doi.org/10.1007/s10531-018-1623$\underline{\mathrm{x}}$

Huband, S., and D. I. McCracken. 2011. Understanding high nature value agriculture in the Romanian Carpathians: a case study. Chapter 1.6 in B. Knowles, editor. Mountain hay meadows. Hotspots of biodiversity and traditional culture. Society of Biology, London, United Kingdom. [online] URL: https://www. mountainhaymeadows.eu/online publication/08-understandinghigh-nature-value-agriculture-in-the-romanian-carpathians-a-casestudy.html

Humbert, J. Y., J. Ghazoul, N. Richner, and T. Walter. 2010. Hay harvesting causes high orthopteran mortality. Agriculture, Ecosystem and Environment 139:522-527. https://doi.org/10.1016/ j.agee.2010.09.012

Humbert, J. Y., J. Pellet, P. Buri, and R. Arlettaz. 2012. Does delaying the first mowing date benefit biodiversity in meadowland? Environmental Evidence 1:9. https://doi. org/10.1186/2047-2382-1-9

Iancu, B., and M. Stroe. 2016. In search of eligibility: common agricultural policy and the reconfiguration of hay meadows management in the Romanian Highlands. Martor 21:129-144.

Ilyés, Z. 2007. Landscape changes and the 18-20th century development of the historical cultural landscape in Gyimes [Title translated from the Hungarian]. Eszterházy Károly High School, Eger, Hungary.

International Society of Ethnobiology (ISE). 2006. ISE code of ethics (with 2008 additions). ISE, Department of Anthropology, University of Florida, Gainesville, Florida, USA. [online] URL: http://ethnobiology.net/code-of-ethics/

Ivaşcu, C., K., Öllerer, and L. Rákosy. 2016. The traditional perceptions of hay and hay-meadow management in a historical village from Maramureş County, Romania. Martor 21:39-51.

Keenleyside C., G. Beaufoy, G. Tucker, G. Jones. 2014. High nature value farming throughout EU-27 and its financial support under the CAP. Report Prepared for DG Environment, Contract
No ENV B.1/ETU/2012/0035, Institute for European Environmental Policy, London, UK. [online] URL: http:// minisites.ieep.eu/assets/1386/HNV and CAP Full Report.pdf

Kuemmerle, T., D. Müller, P. Griffiths, and M. Rusu. 2009. Land use change in southern Romania after the collapse of socialism. Regional Environmental Change 9:1. https://doi.org/10.1007/ s10113-008-0050-Z

Kun, R., S. Bartha, Á. Malatinszky, Z. Molnár, A. Lengyel, and D. Babai. 2019. "Everyone does it a bit differently!": evidence for a positive relationship between micro-scale land-use diversity and plant diversity in hay meadows. Agriculture, Ecosystem and Environment 283:106556. https://doi.org/10.1016/j.agee.2019.05.015

Lasanta, T., J. Arnáez, N. Pascual, P. Ruiz-Flaño, M. P. Errea, and N. Lana-Renault. 2017. Space-time process and drivers of land abandonment in Europe. Catena 149:810-823. https://doi. org/10.1016/j.catena.2016.02.024

Lieskovský, J., P. Kenderessy, J. Špulerová, T. Lieskovský, P. Koleda, F. Kienast, and U. Gimmi. 2014. Factors affecting the persistence of traditional agricultural landscapes in Slovakia during the collectivization of agriculture. Landscape Ecology 29:867-877. https://doi.org/10.1007/s10980-014-0023-1

MacDonald, D., J. R. Crabtree, G. Wiesinger, T. Dax, N. Stamou, P. Fleury, J. Gutierrez-Lazpita, and A. Gibon. 2000. Agricultural abandonment in mountain areas of Europe: environmental consequences and policy response. Journal of Environmental Management 59:47-69. https://doi.org/10.1006/jema.1999.0335

McGinlay, J., D. J. Gowing, and J. Budds. 2017. The threat of abandonment in socio-ecological landscapes: farmers' motivations and perspectives on high nature value grassland conservation. Environmental Science and Policy 69:39-49. https://doi. org/10.1016/j.envsci.2016.12.007

Mikulcak, F., J. L. Haider, D. Abson, J. Newig, and J. Fischer. 2015. Land use policy applying a capitals approach to understand rural development traps: a case study from post-socialist Romania. Land Use Policy 43:248-258. https://doi.org/10.1016/j. landusepol.2014.10.024

Mikulcak, F., J. Newig, A. I. Milcu, T. Hartel, and J. Fischer. 2013. Integrating rural development and biodiversity conservation in Central Romania. Environmental Conservation 40:129-137. https://doi.org/10.1017/S0376892912000392

Molnár Z., A. Kelemen, R. Kun, J. Máté, L. Sáfián, F. Provenza, S. Díaz, H. Barani, M. Biró, A. Máté, and C. Vadász. 2020 Knowledge co-production with traditional herders on cattle grazing behaviour for better management of species-rich grasslands. Journal of Applied Ecology 57:1677-1687. https://doi. org/10.1111/1365-2664.13664

Molnár, Z., J. Kis, C. Vadász, L. Papp, I. Sándor, S. Béres, G. Sinka, and A. Varga. 2016. Common and conflicting objectives and practices of herders and conservation managers: the need for a conservation herder. Ecosystem Health and Sustainability 2(4): e01215. https://doi.org/10.1002/ehs2.1215

Myklestad, Å., and M. Sætersdal. 2004. The importance of traditional meadow management techniques for conservation of 
vascular plant species richness in Norway. Biological Conservation 118:133-139. https://doi.org/10.1016/j.biocon.2003.07.016

Nechita, N. 2003. Flora and vegetation from the Hãşmas massif, Cheile Bicazului and Lacu Roşu [Title translated from the Romanian]. Bibliotheca Historiae Naturalis 2, Piatra-Neamţ, Romania.

Nelson, G. C., E. Bennett, A. A. Berhe, K. Cassman, R. DeFries, T. Dietz, A. Dobermann, A. Dobson, A. Janetos, M. Levy, D. Marco, N. Nakicenovic, B. O’Neill, R. Norgaard, G. PetschelHeld, D. Ojima, P. Pingali, R. Watson, and M. Zurek. 2006. Anthropogenic drivers of ecosystem change: an overview. Ecology and Society 11(2):29. https://doi.org/10.5751/es-01826-110229

Öllerer, K. 2013. On the spatio-temporal approaches towards conservation of extensively managed rural landscapes in CentralEastern Europe. Journal of Landscape Ecology 6:32-46. https:// doi.org/10.2478/v10285-012-0062-8

Page, N., M. Constantinescu, L. Demeter, C. Keenleyside, R. Oppermann, R. Popa, and L. Sutcliffe. 2019. Results-based agrienvironment schemes for support of broad biodiversity at landscape scale in Transylvanian high nature value farmland, Romania. Agreement No. 07.027722/2014/697044/SUB/B2. European Commission, Brussels, Belgium.

Pálfalvi, P. 2010. The floristic list of the Ghimeş-pass area (Eastern Carpathians, Romania) [Title translated from the Hungarian]. Kanitzia 17:43-76.

Plieninger, T., F. Höchtl, and T. Spek. 2006. Traditional land-use and nature conservation in European rural landscapes. Environmental Science and Policy 9:317-321. https://doi. org/10.1016/j.envsci.2006.03.001

Poschlod P., S. Kiefer, U. Tränkle, S. Fischer and S. Bonn. 1998. Plant species richness in calcareous grasslands as affected by dispersability in space and time. Applied Vegetation Science 1:75-90. https://doi.org/10.2307/1479087

Poschlod, P., and M. F. Wallis de Vries. 2002. The historical and socioeconomic perspective of calcareous grasslands - lessons from the distant and recent past. Biological Conservation 104:361-376. https://doi.org/10.1016/S0006-3207(01)00201-4

Reyes-García, V., Á. Fernández-Llamazares, M. Guèze, A. Garcés, M. Mallo, M. Vila-Gómez, and M. Vilaseca. 2016. Local indicators of climate change: the potential contribution of local knowledge to climate research. WIREs Climate Change 7:109-124. https://doi.org/10.1002/wcc.374

Ryan, G. W., and H. R. Bernard. 2003. Techniques to identify themes. Field Methods 15:85-109. https://doi.org/10.1177/1525$\underline{822 \times 02239569}$

Science for Environment Policy. 2017. Agri-environmental schemes: how to enhance the agriculture-environment relationship. Thematic Issue 57. Issue produced for the European Commission DG Environment by the Science Communication Unit, UWE, Bristol, UK. [online] URL: https://ec.europa.eu/ environment/integration/research/newsalert/pdf/ AES impacts on agricultural environment 57 si en.pdf
Solymosi, K. 2011. Indicators for the identification of cultural landscape hotspots in Europe. Landscape Research 36:3-18. https://doi.org/10.1080/01426397.2010.530647

Sólyom, A., B. Knowles, J. Bogdán, G. Rodics, R. Biró, and G. Nyírő. 2011. Small scale farming in the Pogány-havas Region of Transylvania. Farming statistics, agricultural subsidies, the future of farming. Final Report. Pogány-havas Association, Miercurea Ciuc, Romania. [online] URL: http://www.efncp.org/download/ Farming survey short Pogany-havas.pdf

Sutcliffe, L., J. Akeroyd, N. Page, and R. Popa. 2015a. Combining approaches to support high nature value farmland in southern Transylvania, Romania. Hacquetia 14:53-63. https://doi. org/10.1515/hacq-2015-0011

Sutcliffe, L. M., P. Batáry, U. Kormann, A. Báldi, L. V. Dicks, I. Herzon, D. Kleijn, P. Tryjanowski, I. Apostolova, R. Arlettaz, A. Aunins, S. Aviron, L. Balepentienë, C. Fischer, L. Halada, T. Hartel, A. Helm, I. Hristov, S. D. Jelaska, M. Kaligariè, J. Kamp, S. Klimek, P. Koorberg, J. Kostiuková, A. Kovács-Hostyánszki, T. Kuemmerle, C. Leuschner, R. Lindborg, J. Loos, S. Maccherini, R. Marja, O. Máthé, I. Paulini, V. Proença, J. Rey-Benayas, F. X. Sans, C. Seifert, J. Stalenga, J. Timaeus, P. Török, C. van Swaay, E. Viik, and T. Tscharntke. 2015b. Harnessing the biodiversity value of Central and Eastern European farmland. Diversity and Distributions 21:722-730. https://doi.org/10.1111/ddi.12288

Szépligeti, M., Á. Kőrösi, I. Szentirmai, J. Házi, D. Bartha, and S. Bartha. 2018. Evaluating alternative mowing regimes for conservation management of Central European mesic hay meadows: a field experiment. Plant Biosystems 152:90-97. https:// doi.org/10.1080/11263504.2016.1255268

Tudor, M. M. 2015. Small scale agriculture as a resilient system in rural Romania. Studies in Agricultural Economics 117:27-34. http://dx.doi.org/10.7896/j.1503

Tyler, N. J., I. Hanssen-Bauer, E. J. Førland, and C. Nellemann. 2021. The shrinking resource base of pastoralism: Saami reindeer husbandry in a climate of change. Frontiers in Sustainable Food Systems 4:585685. https://doi.org/10.3389/fsufs.2020.585685

Väre, H., R. Lampinen, C. Humphries, and P. Williams. 2003. Taxonomic diversity of vascular plants in the European alpine areas. Pages 133-148 in L. Nagy, G. Grabherr, C. Körner, and D. A. B. Thompson, editors. Alpine biodiversity in Europe. SpringerVerlag, Berlin, Germany. https://doi.org/10.1007/978-3-642-18967-8 5

Wilson, J. B., R. K. Peet, J. Dengler, and M. Pärtel. 2012. Plant species richness: the world records. Journal of Vegetation Science 23:796-802. https://doi.org/10.1111/j.1654-1103.2012.01400.x

Žarnovičan, H., R. Kanka, J. Kollár, M. Vyskupová, A. Sivecká, A. Tichá, S. Fašungová, and D. Kršiaková. 2020. Traditional orchard management in the western Carpathians (Slovakia): evolution between 1955 and 2015. Biologia 75:535-546. https:// doi.org/10.2478/s11756-020-00434-w 
Appendix 1. Trade-offs made by local farmers in order to define the appropriate time of mowing. Ps: time periods studied (P1: 1950-1990, P2: 1990-2007, P3: 2007-2020). Colors of driver categories help the overview of the most important driver categories (green: climate change-related driver; brown: land-use change; blue: direct exploitation; yellow: all the indirect drivers).

\section{Trade-off}

Ps

Driver-categories

P1

- A4. Climate change - increasing frequency of extreme weather events

1.) Labor logistics \# 1: harvesting (mowing) of cereals OR haymaking P1

$\mathrm{P}$

- A5. Land-use change - transformation of natural habitats into agricultura areas or vice versa

- B1. Economic processes, goods and services (e.g. processing, manufacturing, distributing, consuming)

\section{2.) Labor logistics \# 2:} Migration of younger generations and less welltended hay meadows OR youth remain - right time of haymaking, but lack of financial capital P3

\section{$\mathrm{P} 1$}

B2. Demographic - human population

P3 development (size, age structure)

- B5. Cultural drivers - social processes
shaping attitudes, behaviour, values,
beliefs, norms

\begin{tabular}{cl} 
P3 & $\begin{array}{l}\text { A1. Climate change } \\
\text { average temperature }\end{array}$ \\
\hline P3 & $\begin{array}{l}\text { A A2. Climate change }- \text { precipitation } \\
\text { patterns }\end{array}$ \\
\hline
\end{tabular}

$\begin{array}{lll}\text { (P2), P3 } & \begin{array}{l}\text { B1. Economic processes, goods and } \\ \text { services } \\ \text { manufacturing, } \\ \text { consuming) }\end{array} & \begin{array}{r}\text { processing, } \\ \text { distributing, }\end{array} \\ & \end{array}$
3.) Hand mowing:
More financial support from CAP OR greater risk of hay damage in rainy weather P3

\begin{tabular}{c|c} 
& consuming) \\
\hline P3 & $\begin{array}{l}\text { B2. Demographic - human population } \\
\text { development (size, age structure) }\end{array}$ \\
\hline
\end{tabular}

\begin{tabular}{c|c} 
(P2), P3 & $\bullet$ B3. Technological innovations \\
\hline P3 & $\begin{array}{l}\text { - B4. Governance - formal or informal } \\
\text { multi-stakeholder processes }\end{array}$
\end{tabular}

P3

- B5. Cultural drivers - social processes shaping attitudes, behaviour, values, beliefs, norms

4.) Mower machines \# 1: dusty hay OR slower, harder haymaking by scythe P2-P3
- A1. Climate change - increasing average temperature

P2, P3

$\mathrm{P} 2, \mathrm{P} 3$
- A2. Climate change - precipitation patterns

\section{Explanations}

Starting in the 1970s, heavy rainfalls became increasingly frequent. Intensive rain and wind can blow down tall grass vegetation, hindering mowing or advancing the time of mowing.

The labor demand of cereal harvesting delayed mowing of hay. Due to the abandonment of cereal production labor logistics, the area of arable land halved - changes in the labor logistics on family-owned farms.

Cereal production was abandoned due to improved trading conditions - this situation created the chance of better labor logistics and optimized the time of mowing on family-owned farms.

Migration among younger generations is more common, hampering labor logistics during mowing seasons and preventing mowing from taking place at the optimal time.

The loosening of traditions means that mowing at the right time is less important, with an increasing proportion of youngsters working abroad.

Increases in average temperatures make the hay ripen earlier, and it is increasingly difficult to manage the optimal stage of vegetation using hand mowing (it is physically more strenuous as well in increasingly hot summer weather).

Precipitation patterns are increasingly unpredictable, making it harder to define a sufficiently long period when the weather permits mowing by scythe.

Thanks to growing financial capital and the consequent mechanization (mowers, raking machines), fewer farmers are willing to do hand mowing, despite increased subsidies for hand mowing.

There are increasingly fewer able-bodied people available who are in the proper physical condition to carry out hand mowing.

With machinery capable of performing ever more tasks, it is not worth mowing by hand, despite greater financial support for it.

The CAP subsidy system provides a package of increased support to those who mow registered meadows by hand, but prescribed late mowing makes it more difficult to maintain hay of adequate quality.

The simplicity and especially the speed of mechanical mowing is judged increasingly favourably. Time is of growing importance, and a good farmer mows at the right time, regardless of the method.

Machine-mown hay is of poorer quality (it is dustier, because, unlike with hand mowing, anthills cannot be avoided), but because of the higher average summer temperature, mowing must be performed quickly, which is facilitated with machinery.

Haymaking must be done rapidly due to the unpredictability of precipitation patterns - machine mowing aids this, but at the cost of poorer hay quality.

Due to the early onset of spring, on grasslands included in the 
seasons

\begin{tabular}{|c|c|}
\hline $\mathrm{P} 2, \mathrm{P} 3$ & $\begin{array}{l}\text { - A4. Climate change }- \text { increasing } \\
\text { frequency of extreme weather events }\end{array}$ \\
\hline P2, P3 & $\begin{array}{l}\text { - A5. Land-use change - transformation } \\
\text { of natural habitats into agricultural } \\
\text { areas or vice versa }\end{array}$ \\
\hline $\mathrm{P} 2, \mathrm{P} 3$ & $\begin{array}{l}\text { - A7. Direct exploitation / extraction - } \\
\text { overexploitation }\end{array}$ \\
\hline P2, P3 & $\begin{array}{l}\text { - B1. Economic processes, goods and } \\
\text { services (e.g. } \\
\begin{array}{l}\text { manufacturing, } \\
\text { consuming) }\end{array}\end{array}$ \\
\hline P2, P3 & $\begin{array}{l}\text { - B2. Demographic - human population } \\
\text { development (size, age structure) }\end{array}$ \\
\hline
\end{tabular}

- B3. Technological innovations

P3 B4. Governance - formal or informal multi-stakeholder processes

- B5. Cultural drivers - social processes shaping attitudes, behaviour, values, beliefs, norms

\section{5.) Mower machines \# 2:}

longer stubble (greater loss) OR slower, harder haymaking by scythe

P2-P3

B1. Economic processes, goods and services (e.g. processing, manufacturing, distributing, consuming)

P2, P3 $\begin{aligned} & \text { services } \\ & \text { manufacturing, } \\ & \text { consuming) }\end{aligned}$

6.) Time of mowing \# 1: early mowing - short-term benefit of hay quality and long-term loss hampering completion of reproductive cycle $\mathrm{OR}$ vice versa

P1-P2-P3

A2. Climate change - precipitation patterns

P3 A3. Climate change - earlier start of seasons
CAP subsidy system, where mowing cannot be started before $1^{\text {st }}$ of July, it is an important priority to mow the "overripe" hay quickly after that date, before it turns to "straw".

Speed is increasingly important because of the growing frequency of heavy rains, which blow down the hay that grows tall on manured grasslands.

Due to the abandonment of hay meadows at higher altitudes far from the settlement, the increased proportion of managed grasslands to be mowed earlier at lower altitudes, closer to the village, necessitates the expansion of mechanization.

With mower machines, work progresses more quickly, so late-mown grasslands can be dealt with sooner.

Those who cannot afford machinery either have to hire help or mow by hand. This economic situation affects the time of mowing.

Due to the migration of younger generations, the middle generations can make faster progress with haymaking if they can rely on the help of mower machines.

Mower machines speed up mowing, so some of the meadows are mowed earlier, although the hay suffers from poorer quality (dusty) and reduced quantities, as the remaining stubble is longer.

After the date of $1^{\text {st }}$ of July specified by the CAP subsidy system, the ripeness of the vegetation means that mowing must be done quickly, and in this case the large-scale use of mower machines is of great benefit.

In parallel with the loosening of traditions, the spread of machinery and reshaping of grassland management created the opportunity for earlier mowing in large areas of outer (i.e. outlying) hay meadows, and alterations in social institutions.

Due to reductions in livestock numbers, the losses resulting from longer stubble are of decreasing significance, which helps to spread the use of mower machines and to advance the time of mowing.

Due to the increasing average temperature in the different seasons (especially in winter and summer), the vegetation ripens increasingly earlier, so mowing can be carried out sooner.

As the time of mowing shifts ever earlier in the season, it clashes with the end of the period of maximum precipitation in early summer, but the decreasing predictability of rainfall makes it hard to decide on the right time of mowing.

Earlier springs mean the vegetation grows earlier, which also shifts the optimal time of mowing to earlier in the season.

In manured grasslands, the vegetation ripens more quickly, so these grasslands need to be mowed increasingly earlier.

The changing preferences of local farmers often result in them mowing too early in the season. This is a phenomenon that is increasingly prevalent in the landscape.

Investment in the purchase of mower machines allows for earlier mowing than before, even on outer meadows, so more areas can be mowed earlier in the season.

As mower machines become increasingly widely used, outer meadows can also be mowed earlier in the season, so a lot of areas are mowed sooner than before.

The strict regulation of the subsidy system is in direct conflict with the earlier ripening of vegetation.

Increasing average temperatures have a powerful effect on the early ripening of vegetation, and therefore on the time of mowing.

Increasing periods of drought accelerate the over-ripening and drying-out of vegetation, so more hay turns to "straw" in
P3

- A1. Climate change - increasing average temperature
- A2. Climate change - precipitation

\section{7.) Time of mowing \# 2:}

late mowing - long-term stability of the yield and loss of quality OR vice versa P1-P2-P3 


\begin{tabular}{|c|c|}
\hline & patterns \\
\hline P3 & $\begin{array}{l}\text { - A3. Climate change - earlier start of } \\
\text { seasons }\end{array}$ \\
\hline $\mathrm{P} 3$ & $\begin{array}{l}\text { - A6. Land-use change - intensification } \\
\text { or abandonment of agriculture }\end{array}$ \\
\hline P3 & $\begin{array}{l}\text { - A7. Direct exploitation / extraction - } \\
\text { overexploitation }\end{array}$ \\
\hline P3 & $\begin{array}{l}\text { - B2. Demographic - human population } \\
\text { development (size, age structure) }\end{array}$ \\
\hline P3 & $\begin{array}{l}\text { - B4. Governance - formal or informal } \\
\text { multi-stakeholder processes }\end{array}$ \\
\hline P3 & $\begin{array}{l}\text { - B5. Cultural drivers - social processes } \\
\text { shaping attitudes, behaviour, values, } \\
\text { beliefs, norms }\end{array}$ \\
\hline P3 & $\begin{array}{l}\text { - A1. Climate change - increasing } \\
\text { average temperature }\end{array}$ \\
\hline P3 & $\begin{array}{l}\text { - A3. Climate change - earlier start of } \\
\text { seasons }\end{array}$ \\
\hline $\begin{array}{l}\text { P1, P2, } \\
\text { P3 }\end{array}$ & $\begin{array}{l}\text { - A6. Land-use change - intensification } \\
\text { or abandonment of agriculture }\end{array}$ \\
\hline $\mathrm{P} 2, \mathrm{P} 3$ & - B3. Technological innovations \\
\hline P3 & $\begin{array}{l}\text { - B4. Governance - formal or informal } \\
\text { multi-stakeholder processes }\end{array}$ \\
\hline P3 & $\begin{array}{l}\text { - B5. Cultural drivers - social processes } \\
\text { shaping attitudes, behaviour, values, } \\
\text { beliefs, norms }\end{array}$ \\
\hline
\end{tabular}

\section{8.) Aftermath:}

harvesting the hay earlier in order to ensure time to grow aftermath OR allowing completion of reproductive cycle

(P1)-P2-P3 beliefs, norms

- A1. Climate change - increasing
average temperature

- A1. Climate change - increasing
average temperature

\begin{tabular}{cl}
\hline P3 & $\begin{array}{l}\text { - A2. Climate change }- \text { precipitation } \\
\text { patterns }\end{array}$ \\
\hline P3 & $\begin{array}{l}\text { - A3. Climate change - earlier start of } \\
\text { seasons }\end{array}$
\end{tabular}

\section{9.) Species-specific}

\section{haymaking:}

considered species are Poaceae species and some selected Fabaceae species OR Forbs

\section{P1-P2-P3}

- A6. Land-use change - intensification or abandonment of agriculture

P3 A7. Direct exploitation / extraction overexploitation

10.) Key species: Onobrychis viciifolia:

early mowing harvesting good Onobrychis hay OR delayed

- B2. Demographic - human population development (size, age structure)

- B5. Cultural drivers - social processes shaping attitudes, behaviour, values, beliefs, norms

the case of late mowing.

The early start of spring means that the hay ripens sooner, so late mowing may result in decreased quality.

Manuring (also) accelerates the ripening of vegetation, so hay must be mown earlier, otherwise the quality deteriorates rapidly.

Mowing too early in the season (compared to the traditional time) is increasingly prevalent as the quality of the hay takes precedence, so late mowing is no longer as common as it was.

Late mowing may take place owing to outward migration among the youth, not for management reasons, but because of other work carried out in other sectors (difficulties in labor logistics).

The rules of the subsidy system promote late mowing, but this often damages the interests of the farms.

Late mowing is less common due to both the loosening of traditions and the changing preferences of local farmers increased importance of hay quality compared to seed ripening.

Mowing can be done earlier because of the warming climate, which is beneficial to aftermath mowing.

Mowing can begin earlier because of the early onset of spring, which is beneficial to aftermath mowing.

Manuring accelerates the ripening of vegetation, which is beneficial to earlier mowing and aftermath mowing.

Machine mowing promotes faster mowing and is beneficial to aftermath mowing.

The subsidy system hinders aftermath mowing, because permitting mowing only after $1^{\text {st }}$ of July leaves little time for vegetation to re-grow on inner meadows.

The loosening of traditions and the increasing tendency to follow the behaviour of one's neighbours promote early mowing, which is beneficial to aftermath mowing.

The increasing average temperature has heterogeneous effects on the prevalence of plant functional groups (e.g., Poaceae species, forbs), making the decision on the time of mowing more difficult.

The unpredictability of precipitation patterns and the more frequent periods of drought are detrimental to a significant proportion of forb species making the decision on the time of mowing more difficult.

Increasingly early mowing because of the earlier spring and the consequent greening of the vegetation has different effects on local key species, so local farmers have to rethink the time of mowing.

As mountain meadows dominated by forbs were increasingly abandoned, the proportion of manured inner grasslands dominated by the Poaceae functional group increased farmers have to consider the time of mowing to maintain the abundance of important plant functional groups.

Manuring results in the dominance of Poaceae species - the time of mowing plays an important role in shaping the relative abundance of plant functional types.

Mowing too early in the season is beneficial to species that reproduce vegetatively, e.g. Poaceae species.

Paid jobs in other sectors among the younger generation make early mowing increasingly frequent, which benefits vegetatively reproducing species, e.g. Poaceae.

Loosening traditions often cause mowing to be carried out too early in the season, which benefits vegetatively reproducing species, e.g. Poaceae.

Onobrychis, a species of Mediterranean origin, is flowering ever earlier thanks to increasing temperatures, so it also has to be mowed increasingly early.

Al. Climate change - increasing average temperature

A3. Climate change - earlier start of 
mowing supporting completion of the reproductive cycle P1-P2-P3

\begin{tabular}{c|l}
\hline P3 & $\begin{array}{l}\text { A7. Direct exploitation / extraction - } \\
\text { overexploitation }\end{array}$ \\
\hline &
\end{tabular}

P3

B4. Governance - formal or informa multi-stakeholder processes

P3

- B5. Cultural drivers - social processes shaping attitudes, behaviour, values, beliefs, norms

P3

- A1. Climate change - increasing average temperature

P3

- A2. Climate change - precipitation patterns

$\mathrm{P} 2, \mathrm{P} 3$

- A3. Climate change - earlier start of seasons

\section{1.) Livestock condition:} early cut of good quality hay (milk production) OR later mowing and seed ripening P1-P2-P3

P

\begin{tabular}{cl}
\hline P2, P3 & $\begin{array}{l}\text { - A5. Land-use change - transformation } \\
\text { of natural habitats into agricultural } \\
\text { areas or vice versa }\end{array}$ \\
\hline P1, P2, & $\begin{array}{l}\text { A6. Land-use change - intensification } \\
\text { or abandonment of agriculture }\end{array}$ \\
\hline P3 & $\begin{array}{l}\text { A7. Direct exploitation / extraction - } \\
\text { overexploitation }\end{array}$ \\
\hline P3 & $\begin{array}{l}\text { - B4. Governance - formal or informal } \\
\text { multi-stakeholder processes }\end{array}$ \\
\hline P3 & $\begin{array}{l}\text { - B5. Cultural drivers - social processes } \\
\text { shaping attitudes, behaviour, values, } \\
\text { beliefs, norms }\end{array}$
\end{tabular}

- A5. Land-use change - transformation of natural habitats into agricultural areas or vice versa

P1, P2 A2. Climate change - precipitation patterns

\section{2.) Springtime grazing of} hay meadow:

improving the quality of hay and increasing yield security but trampling of carefully managed grasslands OR vice versa

P1-P2

P1, P2 A3. Climate change - earlier start of
seasons

P1, P2 A4. Climate change - increasing
frequency of extreme weather events

P1, A7. Direct exploitation / extraction -
overexploitation

- B1. Economic processes, goods and P1, P2 services (e.g. processing, manufacturing, distributing, consuming)

\begin{tabular}{lll}
\hline 13.) Manure: & & B1. Economic processes, goods and \\
manuring of arable fields OR & services \\
hay meadows & (e.g. & $\begin{array}{l}\text { manufacturing, } \\
\text { processing, } \\
\text { consuming) }\end{array}$
\end{tabular}
$\mathrm{P}$

\section{4.) Manuring:}

Increased quantity of hay (aftermath) OR lower quality (Poaceae dominance) P1-P2-P3
$\mathrm{P} 1, \mathrm{P} 2$,

$\mathrm{P} 3$

- A6. Land-use change - intensification or abandonment of agriculture

- B1. Economic processes, goods and services (e.g. processing, manufacturing, distributing, consuming)

- B4. Governance - formal or informal multi-stakeholder processes influences the time of mowing.

Due to changes that do not follow the ripening of vegetation,

Onobrychis is mowed too early (in flower), reducing the dispersal of seeds and leading to declining yields.

Due to the rules of the subsidy (first date of mowing is $1^{\text {st }}$ of July), Onobrychis can disperse seeds by the time it is mown, but it has no value as hay in this case, its leaves break off, and only the stem remains, although the seeds have been dispersed.

Younger generations regard Onobrychis as of declining importance - many mention that it is disappearing.

The faster development of vegetation due to increasing average temperatures contributes to early mowing.

Periods of drought caused by changing precipitation patterns accelerate the ripening of vegetation and lead to lower hay quality.

Early springs mean that the ideal phenological stage of the vegetation also comes earlier, which affects the time of mowing.

As outer meadows are abandoned, a greater proportion of the hay is produced on inner meadows.

Manuring accelerates the ripening of vegetation and influences the quality and quantity of the mown hay.

Early mowing improves the quality of the hay, but is unfavourable to long-term yields.

As hay quality grows in importance, mowing is carried out ever earlier. This process is rendered impossible by the strict, inflexible rules of the subsidy system.

Due to changes in social capital (traditions, preferences), there is a preference for good-quality hay, and therefore mowing is carried out earlier.

Rainfall at the right time is important for grazing - grass grows after grazing if there is enough precipitation. This is increasingly difficult due to decreasing predictability.

Spring comes early so vegetation develops sooner; livestock can thus be driven earlier to the pastures instead of grazing hay meadows.

Heavy storms that blow down the hay in June have become more frequent since the $1970 \mathrm{~s}$ - if there is no grazing, storms damage the increasingly tall-stemmed vegetation, which advances the time of mowing.

When precipitation is insufficient or at the wrong time, grazing represents overexploitation of the hay meadows and delays the time of mowing.

Farmers do not like to graze livestock on hay meadows that are increasingly treated with manure, which brings forward the time of mowing.

The volume of cereal production influences the amount of manure that remains available for the grasslands, which influences the ripening of the vegetation.

The abandonment of cereal production means there is more manure available for the grasslands, which also encourages secondary growth (aftermath).

Declining livestock numbers lead to a decrease in the available manure, so greater care must be taken when deciding which areas need to be manured.

Manuring brings forward the optimal time of haymaking, but this is prevented by the rules of the subsidies. In most years this is bad for hay quality.

Increasing average temperature brings mowing forward. 

waiting for a longer dry period
to dry the hay OR mowing at the right time P1-P2-P3

16.) Social institutions:

Collaborative, communal haymaking (kaláka) OR haymaking at the right time individually

P3

\begin{tabular}{l|l} 
& - increasing average temperature \\
\hline P3 & $\begin{array}{l}\text { A2. Climate change - precipitation } \\
\text { patterns }\end{array}$
\end{tabular}

- A1. Climate change - increasing average temperature

P3

\begin{tabular}{cl} 
& average temperature \\
\hline P3 & $\begin{array}{l}\text { A3. Climate change - earlier start of } \\
\text { seasons }\end{array}$ \\
\hline
\end{tabular}

P3 A6. Land-use change - intensification or abandonment of agriculture

- B1. Economic processes, goods and services (e.g. processing, manufacturing, distributing, consuming)

\section{7.) Subsidies:}

Support from CAP OR haymaking at the right time P3

\begin{tabular}{|c|c|}
\hline P3 & or abandonment of agriculture \\
\hline P3 & $\begin{array}{l}\text { - B1. Economic processes, goods and } \\
\text { services (e.g. } \\
\text { manufacturing, } \\
\begin{array}{l}\text { consuming) } \\
\text { distributing, }\end{array}\end{array}$ \\
\hline $\mathrm{P} 3$ & - B3. Technological innovations \\
\hline P3 & $\begin{array}{l}\text { - B4. Governance - formal or informal } \\
\text { multi-stakeholder processes }\end{array}$ \\
\hline $\mathrm{P} 3$ & $\begin{array}{l}\text { - B5. Cultural drivers - social processes } \\
\text { shaping attitudes, behaviour, values, } \\
\text { beliefs, norms }\end{array}$ \\
\hline P3 & $\begin{array}{l}\text { - A1. Climate change }- \text { increasing } \\
\text { average temperature }\end{array}$ \\
\hline P3 & $\begin{array}{l}\text { - A3. Climate change - earlier start of } \\
\text { seasons }\end{array}$ \\
\hline P3 & $\begin{array}{l}\text { - A6. Land-use change - intensification } \\
\text { or abandonment of agriculture }\end{array}$ \\
\hline $\mathrm{P} 3$ & $\begin{array}{l}\text { - A7. Direct exploitation / extraction - } \\
\text { overexploitation }\end{array}$ \\
\hline $\mathrm{P} 3$ & $\begin{array}{l}\text { B2. Demographic - human population } \\
\text { development (size, age structure) }\end{array}$ \\
\hline P3 & $\begin{array}{l}\text { - B4. Governance - formal or informal } \\
\text { multi-stakeholder processes }\end{array}$ \\
\hline $\mathrm{P} 3$ & $\begin{array}{l}\text { B5. Cultural drivers - social processes } \\
\text { shaping attitudes, behaviour, values, } \\
\text { beliefs, norms }\end{array}$ \\
\hline
\end{tabular}

Due to the decreasing predictability of precipitation patterns, it is difficult to decide when to mow and when there will be enough time for the hay to dry out.

The increasing average temperature accelerates the ripening of vegetation, which encourages farmers to carry out the mowing individually.

Early springs accelerate the ripening of vegetation, which encourages individual mowing.

Manuring accelerates the ripening of vegetation, which encourages individual mowing.

Purchasing a mower machine allows a farmer to do the mowing alone, without the help of the community.

With a mower machine, even one person working alone can progress quickly without communal assistance.

Due to the strict date set by the CAP ( $1^{\text {st }}$ of July), there is no time for farmers to help each other.

The loosening of traditions also contributes to the decline of collaborative, communal haymaking (kaláka), and farmers are increasingly reluctant to help each other.

Increasing average temperatures accelerate the ripening of vegetation, which conflicts with $\mathrm{CAP}$ rules on the time of mowing.

Early spring accelerates the ripening of vegetation, which conflicts with CAP rules on the time of mowing.

Manuring accelerates the ripening of vegetation, which conflicts with CAP rules on the time of mowing.

Mowing too early (based on the views of the local farmers) in the season is increasingly prevalent as the quality of hay becomes more important, which makes it harder to take account of the date set by the subsidy system.

Due to migration, the traditional labor logistics of familyowned farms no longer apply, and younger generations frequently do the mowing when their other jobs allow, with grassland management aspects playing a secondary role.

The CAP subsidy system regulates the time of mowing, and farmers only receive financial support if they meet the requirements of the regulations.

The increasingly early start date of mowing, resulting from the loosening and changing of traditions, conflicts with the compulsory date of $1^{\text {st }}$ of July. 